\title{
EFFICIENCY OF CENTRAL BANK POLICY DURING THE CRISIS: ROLE OF EXPECTATIONS IN REINFORCING HOARDING BEHAVIOR
}

\section{Volha Audzei}
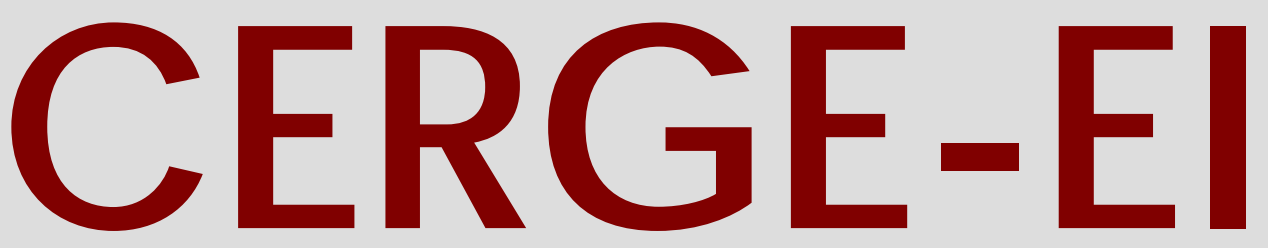

Charles University Centerfor Economic Research and Graduate Education Academy of Sciences of the Czech Republic Ec onomic Institute 


\section{Working Paper Series (ISSN 1211-3298)}

\section{Efficiency of Central Bank Policy \\ During the Crisis: \\ Role of Expectations in Reinforcing \\ Hoarding Behavior}

Volha Audzei

CERGE-EI

Prague, December 2012 
ISBN 978-80-7343-281-2 (Univerzita Karlova. Centrum pro ekonomický výzkum a doktorské studium)

ISBN 978-80-7344-273-6 (Národohospodářský ústav AV ČR, v.v.i.) 


\title{
Efficiency of Central Bank Policy During the Crisis: Role of Expectations in Reinforcing Hoarding Behavior ${ }^{1} 2$
}

\author{
Volha Audzei ${ }^{3}$ \\ CERGE-EI ${ }^{4}$
}

December 2012

\begin{abstract}
Investor sentiment proved to be an important factor during the recent financial and current euro crises. At the same time many existing general equilibrium models do not account for agents' expectations, market volatility, or over-pessimism of investors' forecasts. In this paper we incorporate into the DSGE model a financial sector populated by a continuum of banks with heterogeneous forecasts. We simulate the model with expectational shocks calibrated by the values observed during the financial crisis. Our results suggest that expectational shocks alone could generate a recession of a magnitude comparable to the recent crisis. We then conduct a simple exercise to mimic the credit support policy of a central bank. The results indicate that without influencing agents' expectations, the liquidity provision alone reduces the magnitude of the recession, but neither stops it nor shortens its duration. One reason for low efficiency of the policy in our model is that banks hoard the liquidity provided by a central bank.

Keywords: Financial Intermediation, Expectations, DSGE, Liquidity Provision JEL codes: E22, E32, G01, G18

\footnotetext{
${ }^{1}$ I wish to thank Sergey Slobodyan, Michal Kejak, Filip Matejka, Kristoffer P. Nimark, Liam Graham, and Michal Pakos for helpful suggestions. All remaining errors are the responsibility of the author.

${ }^{2}$ The work was supported by the grant SVV-2012-265 801. The financial support of the Czech Science Foundation project No. P402/12/G097 DYME Dynamic Models in Economics is acknowledged

${ }^{3}$ e-mail: vaudzei@cerge-ei.cz

${ }^{4}$ CERGE-EI, a joint workplace of Charles University in Prague and the Economics Institute of the Academy of Sciences of the Czech Republic, Politickych veznu 7, 11121 Prague, Czech Republic.
} 


\begin{abstract}
Očekávání investoů se ukázal jako důležitý faktor v průběhu nedávné finanční krize a současné eurokrize. Mnoho modelů všeobecné rovnováhy ale nebere v potaz očekávání agentů, volatilitu trhů ani nadměrný pesimismus předpovědí investorě. $\mathrm{V}$ tomto článku začleňujeme do DSGE modelu finanční sektor s kontinuem bank, které vytvářejí rozdílné předpovědi. Model je simulován se šoky do očekávaní, které jsou kalibrované na základě dat z období finanční krize. Naše výsledky naznačují, že šoky do očekávání mohou vygenerovat recesi závažností srovnatelnou s nedávnou krizí. Následně se snažíme namodelovat politiku úvěrových podpor, kterou vykonávaly centrální banky. Výsledky ukazují, že bez vlivu na očekávání agentů pouhé dodávání likvidity sice snižuje hloubku recese, ale nezastaví ji ani nezkrátí její dobu trvání. Jeden z důvodů nízké efektivity této politiky v našem modelu je, že banky hromadí likviditu, která je poskytována centrální bankou.
\end{abstract}




\section{Introduction}

The recent financial crisis was one of the deepest and longest in modern history. Having started within the financial sector, it then spread into the real economy, causing a recession the length of which has yet to be determined. Not surprisingly, it draw the attention of the academics and policy makers to the interconnection of the financial and real sector. The crisis has also been a reminder that market imperfections and the limited rationality of economic agents are real life phenomena, able to generate deep and severe recessions. Another recent example of market failure is the ongoing debt crisis in the Eurozone which (putting aside the questions of fiscal discipline) has revealed the existence of asymmetric information in the bond market and undervaluation of the risk and importance of investor sentiment.

Thus, the expectations of economic agents and their uncertainty about the future are important factors in generating economic fluctuations. Expectations about the future path of economic variables affect the future development of these variables, and thus amplify or dampen government and central bank policy effects. These expectations may be based on forecasts of the fundamentals or on expert opinions. Either way, they are subject to errors and do not take into account their self-fulfilling nature and their influence on the expectations of others.

This study aims to contribute to the literature by focusing on the connection between the financial and the real sector and incorporating imperfect market expectations and market sentiment in a DSGE model. Such an enriched model is able to replicate a drop in investment and a freeze in the credit market, and thus could provide intuition about the efficiency of possible policy actions during the crisis.

The main contribution of this paper is the introduction of heterogeneous financial intermediaries (which we call banks) with imperfect information into a DSGE model. Heterogeneity takes the form of different expert opinions about asset returns. Expert opinions take the form of subjective interpretations of publicly available news about future economic conditions. As is quite common in forecasting practice, these expert opinions are then used to adjust econometric forecasts. In our model, expert opinions are not pure noise, but rather noisy interpretations of the fundamental process. As in Bullard et al. (2010), noise appears when agents misinterpret news about the future changes in fundamentals. How noisy the opinions are reflects how strongly agents overreact to pessimistic or optimistic news. Our modeled banking sector features 
an interbank market through which optimistic banks borrow from pessimistic ones subject to collateral constraints. The risky asset considered in the model represents an investment into the real economy, such that a decline in banks' expectations generates a drop in real activity. Thus, in our model frictions arise from a shock to the banks' expectations about economic activity which spillover into the real sector through the credit channel. In equilibrium the moments of beliefs' distribution and the market volatility enter the model as state variables. With the number of expert surveys and market volatility indices at hand, our developed framework becomes a tractable version of a DSGE model to analyze the role of expectational shocks and their propagation into the real economy. One could also consider the question about efficiency of the policy measures during the economic downturn.

Our findings suggest that investors' expectations and their uncertainty are able to generate large swings in the real economy, where manufacturers are dependent on credit. With the sentiment shocks calibrated on the values observed during the recent crisis, the model generates dynamics comparable to the observed values. We then consider a highly stylized analogue of liquidity provision policy in which investors are provided with central bank money. We show that absent any policy costs, in our model the policy dampens the magnitude of the crisis but neither stops it nor decreases its duration. Moreover, with investors concerned about the prospects of the real economy, a significant share of funds received from the central bank is invested in safe assets or kept in reserves instead of crediting the real economy. This result is in line with the banks' observed behavior. The results also suggest that making any policy evaluation without accounting for investors' sentiment and market volatility may overstate policy efficiency.

The paper is related to several strands of literature. First, it is related to studies which reconsider the assumption that agents are identical and make rational decisions based on perfect information. Fuhrer (2011) and Beaudry et al. (2011), for instance, show empirically that sentiment shocks generate economic volatility. The role of uncertainty and its devastating effects on the economy is described in Bloom (2009). Boz and Mendoza (2010) show how waves of over-optimism and over-pessimism are generated in an environment in which agents have to learn about asset returns. Grauwe (2010) considers a DSGE model with imperfect information, but without the explicit role of the financial sector. Bullard et al. (2010) study the role of expert adjustments of economic forecasts for homogeneous agents. Sims 
(2003) introduces the concept of rational inattention, in which agents choose to which bits of information to allocate their attention subject to information capacity constraints, and shows that it accounts for delayed and smooth market responses to macroeconomic shocks. Kurz and Motolese (2010) use the concept of rational beliefs formed as a model, which can't be rejected by the empirical evidence. They conclude that risk premia are affected significantly by the beliefs' dynamics, which is also the source of asset price volatility. Their research supports the claim (which we also make) that diversity of beliefs is a crucial factor in analyzing financial markets and in forecasting agents' behavior.

The idea that agents' heterogeneity could generate large fluctuations over the business cycle is supported by Lorenzoni (2009). Introducing heterogeneity in consumers' expectations about productivity in an otherwise standard New Keynesian model, he builds a framework capable of generating large swings in output, inflation and unemployment endogenously. Banks' heterogeneity in a DSGE model is introduced by Hilberg and Hollmayr (2011), who study the policy of liquidity provision and relaxing the collateral constraints. In Hilberg and Hollmayr (2011) banks' heterogeneity is caused by their exogenous separation on investment and commercial banks, and only investment banks are allowed to borrow from the central bank. We consider a different structure of the interbank market - a number of ex-ante identical banks who differ ex-post depending on their subjective interpretation of public information.

Another strand of research related to our paper concentrates on the role of the financial sector and credit in the economy. There have been studies incorporating the banking sector in general equilibrium models. Examples of such research are Gertler and Karadi (2011), Curdia and Woodford (2011), Negro et al. (2011), and Gertler and Kiyotaki (2010). Having introduced the financial sector, these papers address the central bank's policy to mitigate crisis. Whereas the first two papers consider the effect of the policy on the transfer of credit between households and financial intermediaries, the latter two analyze credit supply to entrepreneurs subject to a liquidity constraint of the Kiyotaki and Moore (2008) type. Most of these papers (aside from Curdia and Woodford, 2011) conclude that the policy unambiguously helped to escape a far more severe recession. Curdia and Woodford (2011) condition the relevance of the policy on its implementation and an agents' perception of future interest-rate path. In our study we also address the efficiency of central bank policy, 
but account for the role of sentiment and imperfect expectations among the investors.

Our model differs from the studies above in emphasizing the importance of a different type and place of the friction: informational friction between the financial and the real sector. This friction takes the form of imperfect information and investors sentiment on the banks' side, leading to an under or oversupply of credit to the real sector. This allows us to account for "hoarding" behavior by the banks, observed during the crisis, often missing in DSGE models which analyze unconventional central bank policy. Hoarding was observed as banks' reluctance to provide credit, while keeping funds in excessive reserves or investing in short-term assets ${ }^{5}$. Our interpretation is that investors were reluctant to lend not only because they were fund constrained but, in part, due to pessimistic return expectations or high market volatility. The Bank Lending Survey for the Euro Area conducted by the ECB indicates just how expectations of future economic activity and liquidity shortage "compete" for influence on bank credit in the Euro Area (figure 1). Figure 1 gives insights into the concerns of Euro Area banks during the recent crisis: liquidity shortage and expectations of economic activity were both influential in banks' lending decisions. Expectations of low economic activity contributed to tightening of the credit standards by more than $70 \%$ percent of the banks surveyed; more than $20 \%$ of the banks tightened their credit standards due to their liquidity position. Therefore, both factors - expectations of economic activity and liquidity shortage should be addressed when examining the central bank's policy, a point sometimes neglected in the literature.

There are empirical studies which tackle the question of the role of liquidity and counterparty risk during crisis. Taylor and Williams (2008) and McAndrews et al. (2008) studied the effect of the introduction of TAF (term auction facility) by the Fed on three-month LIBOR. While the former study concludes that the introduction of TAF did not have a significant effect on credit spread, which also means that it was a counterparty risk that drove credit spreads up, the latter study comes to a different conclusion. Further studies confirming the positive effect of liquidity provision in crisis have been done by Christensen et al. (2009), Donati (2010), and Avouyi-Dovi and Idier (2011). This last paper, focusing on the French bond market, also finds that if there is no crisis (as identified by debt market and

\footnotetext{
${ }^{5}$ For the evidence on hoarding see Gale and Yorulmazer (2011), Heider et al. (2009) and references therein.
} 
Over the past three months, how have the following factors affected your bank's credit standards as applied to the approval of loans or credit lines to enterprises?

Your bank's liquidity position

\section{Expectations regarding general economic activity}
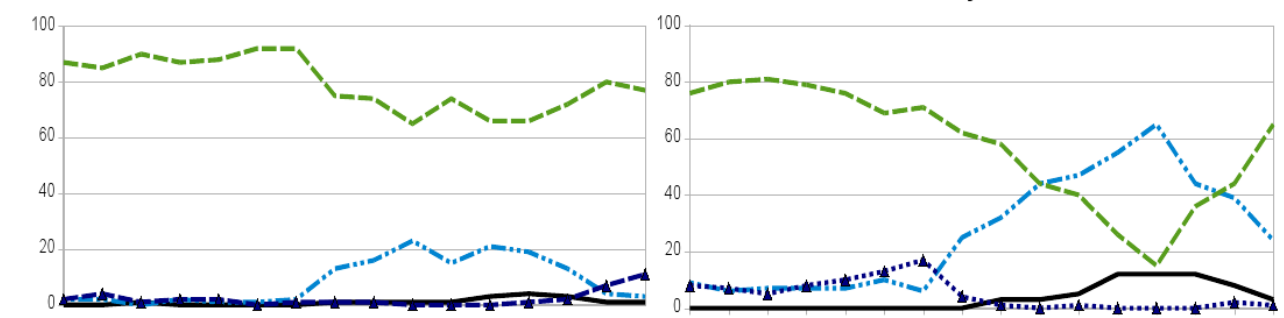

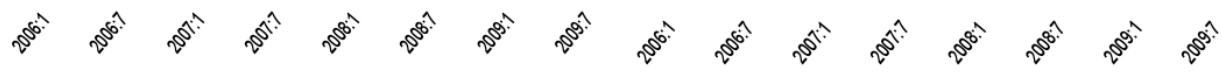
- Contributed tightening

- Contributed somewhat to

Figure 1: Effect of Liquidity Position and General Economic Activity on Banks' Credit Standards Source: ECB Bank Lending Survey 
monetary policy cycles) then liquidity provision increases the probability of a crisis occurrening.

The paper proceeds as follows. Section 2 describes the model set-up. In section 3 we present calibrated parameter values and shocks. We then simulate the model to consider the importance of sentiment and fundamental shocks. With sentiment shocks calibrated as the values observed during the recent crisis, we simulate the model and study its reaction to a policy of liquidity provision. Section 4 concludes.

\section{Description of the Model}

The model economy consists of two blocks. The first one is inhabited by standard DSGE agents - a representative household, competitive capital good producers, monopolistic final good producers, and the government (combined with the central bank). The second block is populated by modified intermediate good producers and financial intermediaries - banks. Intermediate good producers are perfectly competitive firms and are identical. Each period they borrow funds from banks to buy capital and pay back a return on capital in the next period. The return on capital depends on the product of capital and the resale value of undepreciated capital. Similar to Gertler and Kiyotaki (2010) and Gertler and Karadi (2011) the amount of undepreciated capital depends on capital quality. In our model capital quality is a persistent process and is subject to two kinds of shocks - a persistent one and a temporary one. The current value of capital quality is observable to all sectors; however, the agents do not know the structure of the shocks and, consequently, do not observe which of the shocks have occurred. Bankers do their best to predict the future value of capital quality using Bayesian updating, yet without knowledge of the structure of the law of motion, they never learn its true parameters. This generates uncertainty in bankers' return and makes the investment into capital risky. Being completely rational, bankers update their econometric forecast (based on past realizations and estimated parameters) with expert opinions, which are noisy signals about the future values of capital quality. The intuition behind expert opinions comes from Kurz (1994) and Kurz and Motolese (2010), who emphasize the role of qualitative signals - pieces of news which cannot be transformed into aquantitative forecast unambiguously. A similar structure is modeled in Bullard et al. (2010), but 


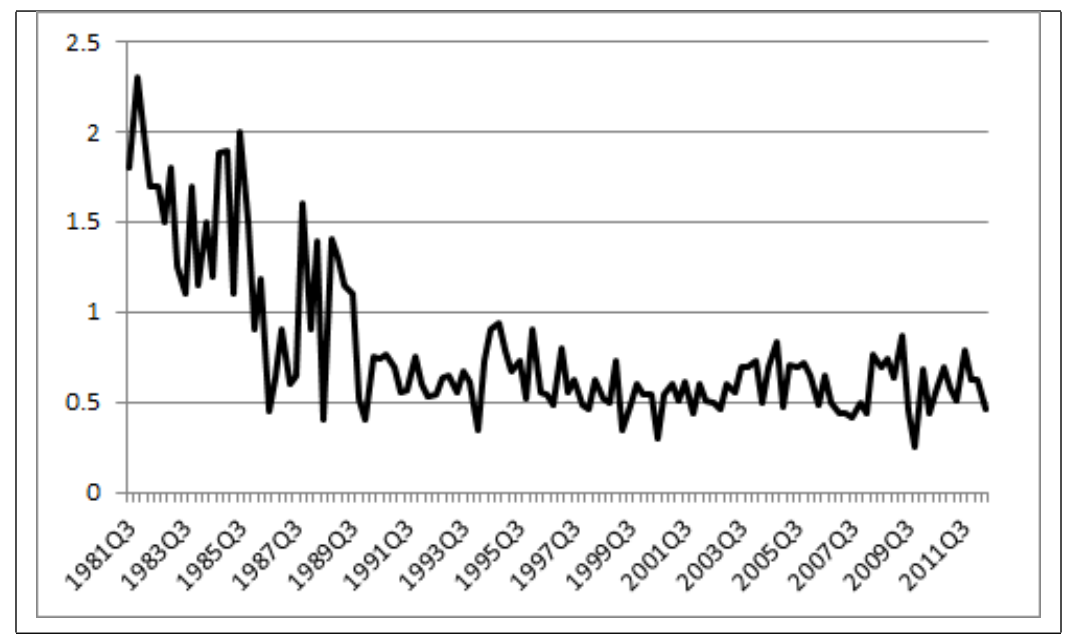

Figure 2: Cross-Sectional Dispersion for Quarterly Forecasts for AAA Corporate Bond Yield (for 4 quaters ahead) Source: Survey of Professional Forecasters by Federal Reserve Bank of Philadelphia

for homogeneous agents. As a result, in our model there is a continuum of banks with diversified beliefs about future return, all of beliefs are in principle noisy. The heterogeneity of banks' assessments about the return on capital claims gives rise to the interbank market, where optimistic banks borrow from the pessimistic ones against collateral. Thus, the amount of capital in this economy depends on bankers' sentiment - more specifically, on the parameters of the distribution of beliefs.

The question could be raised here: Why do banks' beliefs not converge if banks can observe or reveal the beliefs of other banks? The evidence on market forecasts suggests that investors have different beliefs (which, though, might be correlated). As an example, consider the Cross-Sectional Dispersion for Quarterly Forecasts for AAA Corporate Bond Yield (for 4 quarters ahead) from the Survey of Professional Forecasters by the Federal Reserve Bank of Philadelphia (figure 2). As is clear from figure 2, the forecasts exhibit persistent diversity. The difference in forecasters' predictions is time-varying, but it never disappears. We do not intend to model why heterogeneity does not disappear, but rather, incorporate the behavior observed in the markets into a theoretical model.

In what follows we consider the blocks of the model in detail. 
Intermediate Good Producers The sector is perfectly competitive. Producers combine labor and capital using Cobb-Douglas production function:

$$
Y_{t+1}=A_{t+1} K_{t}^{\alpha} L_{t}^{1-\alpha}
$$

where $K_{t}$ stands for capital, $L_{t}$ stands for labor and $A_{t}$ is total factor productivity.

Focusing on expectational shocks in this paper, we abstract from any uncertainty about productivity and set $A_{t}=A=1$. The timing is as follows: in period $t$ producers and the household sign a contract for labor for $t+1$, and wage for $t+1$ is determined by the market. The investment into capital should be made one period in advance, that is, to produce in period $t+1$ the investment should be made in period $t$.

To invest in the next period's capital, $K_{t}$, intermediate good producers issue claims $S_{t}$ for the price $Q_{t}^{S}$, so that

$$
Q_{t}^{K} K_{t}=Q_{t}^{S} S_{t}
$$

In the next period intermediate good producers sell the output to the final good producers at price $P_{m, t+i}$ and the depreciated capital to capital producers at market price $Q_{t+1}$. Because of the perfect competition among intermediate good producers, $Q_{t}^{K}=Q_{t}^{S} \equiv Q_{t}$. The amount of depreciated capital is equal to $(1-\delta) \zeta_{t+1} K_{t}$, where $\delta$ is the physical depreciation rate and $\zeta_{t+1}$ reflects "capital quality" as in Gertler and Kiyotaki (2010) and Gertler and Karadi (2011).

At $t+1$, the firm pays $R_{k, t+1}$ to the bankers per each unit of investment. As firms are identical, investment into capital pays the same return for all banks.

Formally, an intermediate good producer's problem is:

$$
\max _{K_{t}, L_{t}} E_{t} \Omega_{t, t+1} \times\left[P_{m, t+1} Y_{t+1}+(1-\delta) \times \zeta_{t+1} Q_{t+1} K_{t}-R_{k t+1} Q_{t} S_{t}-W_{t} L_{t}\right]
$$

where $E_{t} \Omega_{t, t+1}$ is a discount factor of the households (to be defined late) and $W_{t}$ 
is the nominal wage, subject to

$$
Q_{t} K_{t}=Q_{t} S_{t}
$$

and to the demand for $S_{t}$ by the financial sector (defined later).

Equation (3) states that in each period an intermediate good producer maximizes profit which consists of the revenues from production and resale of the depreciated capital net of labor payment and payment on claims $S_{t}$.

first-order conditions define the return on capital paid to the bankers and the firm's demand for labor and capital:

$$
\begin{gathered}
{\left[K_{t}\right] E_{t}\left[\Omega_{t, t+1}\left(Q_{t} R_{k t+1}-\left[\alpha \frac{P_{m, t+1} Y_{t+1}}{K_{t}}+(1-\delta) Q_{t+1} \zeta_{t+1}\right]\right)\right]=0} \\
{\left[L_{t}\right](1-\alpha) E_{t}\left[\frac{P_{m, t+1} Y_{t+1}}{L_{t}}-W_{t}\right]=0}
\end{gathered}
$$

The first-order conditions determine the expected return on the firm's claim as the expected value of the marginal product of capital plus the expected resale value of the capital divided by the price of the claim. Wage is then determined by the expected value of the marginal product of labor.

Because of perfect competition, the price of the intermediate good producer equals the marginal cost of production:

$$
P_{m, t}=R_{k t}^{\alpha} W_{t-1}^{1-a}\left(\left(\frac{1-\alpha}{\alpha}\right)^{\alpha}+\left(\frac{1-\alpha}{\alpha}\right)^{\alpha-1}\right)
$$

We model capital quality as a process observable by all the sectors, but with an unknown law of motion. With this process we intend to capture developments in capital value which are not perfectly predictable by the market, so that investors do not have perfect prediction of risky asset (capital) return. We assume the following process for capital quality, $\zeta_{t}$ :

$$
\zeta_{t}=\rho_{\zeta} \zeta_{t-1}+\mu_{t}+\varepsilon_{\zeta, t}
$$

$\mu_{t}$ is a persistent shock

$$
\mu_{t}=\rho_{\mu} \mu_{t-1}+v_{t}
$$


where $\rho_{\mu}$ and $\rho_{\zeta}$ are persistence parameters, $v_{t}$ and $\varepsilon_{\zeta, t}$ are transitory Gaussian shocks, serially uncorrelated with zero contemporaneous correlation and variances $\sigma_{v}$ and $\sigma_{\varepsilon}$. Neither the intermediate good producer nor the banks observe either $\mu_{t}$ or $\varepsilon_{\zeta, t}$, therefore they cannot learn the true law of motion of $\zeta$.

Financial Intermediaries There are $H$ banks in the economy, with $H$ normalized to one. Banks choose between investing in safe and risky assets maximizing one period revenue. The risky asset in this economy are the claims of intermediate good producers, $S_{t}$, with uncertain return $R_{k, t+1}$. There is also an interbank market where banks lend to each other, $B_{t}^{i, h}$, against collateral, with the interbank gross interest rate $R_{t}^{i}$. The interbank market is modeled as safe, so that interbank lending becomes a safe asset. The claims of intermediate good producers serve as collateral. As shown below, the collateral constraint is such that there is no risk in the interbank market. The banks have an alternative safe investment, $N_{t}$, issued by the central bank with return $R_{t}^{N}$. We interpret $N_{t}$ as holding money in central bank reserves. The banks attract deposits, $D_{t}$, from the household. For simplicity, we assume that each bank gets the same amount of deposits, so that $D_{t}^{h}=\frac{D_{t}}{H}$.

Beliefs Adopting the intuition of Kurz (1994), we assume that banks have heterogeneous beliefs about future states of the economy. They have access to past data on returns. They also understand that they cannot learn the true parameters in (8) based on that past information and that a prediction based on past information only is imprecise. There is, however, qualitative information - news - about the future ${ }^{6}$, which can influence their beliefs about the swings in returns. News are interpreted differently by each bank, even though the interpretation could be correlated ${ }^{7}$. Banks "update" their predictions based on past values using information from the news as in Bullard et al. (2010). News are associated with different pieces of qualitative information at each period of time (R\&D investments always result in the invention of new technology, political uncertainty in different parts of the world influences different stock prices), so that the ex-post informativeness of this information does not

\footnotetext{
${ }^{6}$ e.g. information about large investment in $\mathrm{R} \& \mathrm{D}$, political elections, corporate mergers etc. any event that might influence future returns, but whose effect could not be unequivocally translated into a numerical forecast.

${ }^{7}$ e.g. there could be disagreement about the size of the effect, but an agreement if the effect is positive or negative.
} 


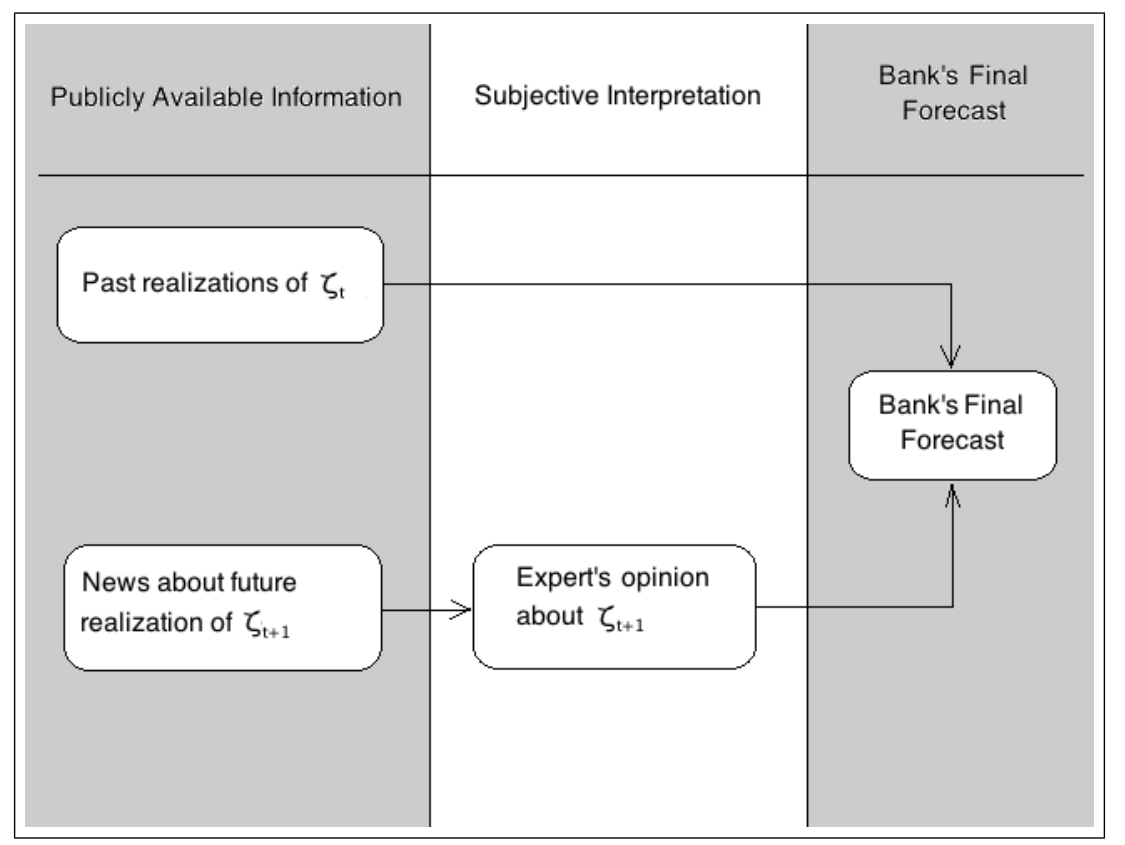

Figure 3: Formation of Bank's Forecast

predict its usefulness in the future. Although based on the news, expert opinions tend to be persistent. That is, an expert who, in the previous period, believed in extra high returns is not likely to predict losses for the next period, yet she might predict a lower return if she received unfavorable news.

Belief formation is illustrated in figure 3. Banks form their priors about $\zeta_{t+1}$ based on past data and then add the expert adjustment $\theta_{t}^{h}$. Banks cannot observe either $\mu_{t-1}$ or $v_{t}, \varepsilon_{\zeta, t}$ and the perceived law of motion for $\zeta$ is:

$$
\zeta_{t}=\hat{\rho}_{\zeta, t} \zeta_{t-1}+\nu_{t}
$$

When the new observation on $\zeta_{t}$, arrives the priors about $\hat{\rho}_{\zeta, t}$ and $\sigma_{\nu}^{2}$ are updated using Bayes' rule.

Hence, the banks ' priors are formed as:

$$
\begin{gathered}
E_{t}\left(\tilde{\zeta}_{t+1} \mid \zeta^{t}\right)=\hat{\rho}_{\zeta, t} \zeta_{t} \\
\operatorname{Var}_{t}\left(\tilde{\zeta}_{t+1} \mid \zeta^{t}\right)=\hat{\sigma}_{\nu, t}^{2}
\end{gathered}
$$

The prior of the future value of capital quality is then updated by the bank as a 
weighted average of the signal and estimation from the past data:

$$
E_{t} \hat{\zeta}_{t+1}^{h}=s E_{t}\left(\tilde{\zeta}_{t+1} \mid \zeta^{t}\right)+(1-s) \theta_{t}^{h}
$$

where (1-s) is the share of expert opinion in the final prediction.

Adopting the adjustment procedure from Bullard et al. (2010) but for heterogeneous agents, we let expert opinion be formed as:

$$
\begin{gathered}
\theta_{t}^{h}=\rho_{\theta} \theta_{t-1}^{h}+\left(1-\rho_{\theta}\right) \eta_{t}^{h} \\
\eta_{t}^{h}=\zeta_{t+1}+\varepsilon_{\eta, t}^{h}
\end{gathered}
$$

$\varepsilon_{\eta, t}^{h} \sim U(a, b)$, with $a, b$ beeing the bounds of the distribution . The coefficient in (14), $\rho_{\theta}$, reflects the persistence of banks' beliefs, $\varepsilon_{\eta, t}^{h}$ is idiosyncratic noise in the expert's opinion, and $a$ and $b$ are the bounds of the shock distribution. As a result, the experts' adjustments also follow a uniform distribution with the bounds: $\theta_{t}^{h \sim} U\left(\theta_{t}^{\min }, \theta_{t}^{\max }\right)^{8}$. Thus, experts' opinions are on the one hand persistent and, on the other hand, contain information about fundamental process.

In our model the following moments of belief distribution enter as state variables: average market belief, dispersion of beliefs and variance of beliefs.

Because the econometric forecast is the same for all the banks (they differ only in the expert opinion about the future), the average belief is:

$$
\bar{E}_{t} \hat{\zeta}_{t+1}=s E_{t}\left(\tilde{\zeta}_{t+1} \mid \zeta^{t}\right)+(1-s)\left(\rho_{\theta} \bar{\theta}_{t-1}+\left(1-\rho_{\theta}\right) \bar{\eta}_{t}\right)
$$

As the experts' opinions are correlated among banks, expert opinion error does not vanish when averaging.

We measure dispersion of beliefs as a standard deviation of experts' opinions:

$$
\sqrt{\frac{\left(\theta_{t}^{\max }-\theta_{t}^{\min }\right)^{2}}{12}}
$$

\footnotetext{
${ }^{8}$ The expert's adjustments follow the uniform distribution with the bounds $\left(\theta_{t}^{\min }, \theta_{t}^{\max }\right)$, where $\theta_{t}^{\min }=\left(1-\rho_{\theta}\right) \sum_{i=0}^{t} \rho_{\theta}^{t-i} \zeta_{i+1}+\left(1-\rho_{\theta}\right) \sum_{i=0}^{t} \rho_{\theta}^{t-i} a$ and $\theta_{t}^{\max }=\left(1-\rho_{\theta}\right) \sum_{i=0}^{t} \rho_{\theta}^{t-i} \zeta_{i+1}+$ $\left(1-\rho_{\theta}\right) \sum_{i=0}^{t} \rho_{\theta}^{t-i} b$
} 
And the variance of banks' forecasts is given by

$$
s^{2} \hat{\sigma}_{\nu, t}^{2}+(1-s)^{2} \frac{(b-a)^{2}}{12}
$$

That is, in our notation variance reflects how noisy the banks' final forecasts are, while dispersion reflects how different they are.

Interbank Market We model the interbank market as a risk-free market. Thus, we focus on the heterogeneity of beliefs among bankers and their beliefs about collateral value, but not about other banks' solvency. The banks have to issue collateral in order to obtain credit from other banks. The collateral constraint is formulated in accordance with Geanakoplos (2009). The asset serving as collateral is the risky asset $S_{t}$. There are no other costs for banks defaulting on their obligations except losing the collateral. Thus

$$
\text { payment on } B_{t}^{i}=\min \left\{C o l_{t}, R_{t}^{i} B_{t}^{i}\right\}
$$

where $B_{t}^{i}$ is the amount of interbank debt issued at $t$;

$R_{t}^{i}$ is the interbank interest rate;

$\mathrm{Col}_{t}$ is the amount of collateral issued to back up the debt.

Equation (16) states that payment on the interbank credit will not be higher than the collateral value. The lenders, anticipating borrowers' behavior in period $t+1$, do not lend in period $t$ more than the present discounted value of the collateral:

$$
B_{t}^{i, h} \leq \frac{C o l_{t}}{R_{t}^{i}}
$$

Focusing on the low-risk interbank loans, we set $\operatorname{Col}_{t}=\min E_{t} \hat{R}_{k, t+1}^{h}$. That is, the banks have minimal risk to get their loan back whatever actual realization of borrowers investment income is. From (5) it follows that the minimal expected return (when $E_{t} \zeta_{t+1}=0$ ) is:

$$
\min E_{t} \hat{R}_{k, t+1}^{h}=E_{t} \frac{P_{m, t+1} \alpha Y_{t+1}}{K_{t}} \equiv r_{\min }
$$

The amount of collateral and interbank credit for each borrower must satisfy: 


$$
B_{t}^{i, h}<=\frac{E_{t} \frac{P_{m, t+1} \alpha Y_{t+1}}{K_{t}} S_{t}^{h}}{R_{t}^{i}}
$$

Banks' Problem Finally, the $h^{\prime} s$ bank problem is:

$$
\max _{S_{t}^{h}, N_{t}^{h}, B_{t}^{i, h}} E_{t} \Omega_{t, t+1}\left(\widehat{E}_{t}\left(\Pi_{t+1}^{h}\right)-\frac{\rho \widehat{\operatorname{Var}}\left(\Pi_{t+1}^{h}\right)}{2}\right)
$$

subject to budget constraint:

$$
Q_{t} S_{t}^{h}+N_{t}^{h}=\Pi_{t}^{h}+D_{t}^{h}+B_{t}^{i, h}
$$

and collateral constraint for a borrower on the interbank market:

$$
B_{t}^{i, h}<=\frac{E_{t} \frac{P_{m, t+1} \alpha Y_{t+1}}{K_{t}} S_{t}^{h}}{R_{t}^{i}}
$$

where $\Pi_{t}^{h}$ is the bank's own funds and

$$
\Pi_{t}^{h}=R_{k t} S_{t-1}^{h}+R_{t-1}^{N} N_{t-1}^{h}-R_{t-1}^{i} B_{t-1}^{i, h}-R_{t-1} \frac{D_{t-1}}{H}
$$

where if the bank is a lender then $B_{t}^{i, h}<0$ and $-R_{t-1}^{i} B_{t-1}^{i, h}>0$ is its income from lending, and on the contrary, if the bank is a borrower then $B_{t}^{i, h}>0$ and $-R_{t-1}^{i} B_{t-1}^{i, h}<0$ is the payment it makes on the loan; $S_{t}^{h}$ is the investment into claims of intermediate good producers, $N_{t}$ - into reserves. $R_{k t}, R_{t-1}^{N}, R_{t-1}^{i}$ are returns on risky asset, reserves and interbank loan, respectively. A detailed solution to the banks' problem is in appendix A.

The rest of the model is standard, though simplified, DSGE model blocks with rational expectations.

Household There is a representative household in the economy, which solves the following problem: 


$$
\begin{aligned}
& \max _{C_{t}, L_{t}, D_{t}} E_{t} \sum_{i=0}^{\infty} \beta^{i}\left[\ln \left(C_{t+i}\right)-\frac{\chi}{1+\varphi} L_{t+i-1}^{1+\varphi}\right] \\
& \text { s.t. } P_{t} C_{t}+D_{t}=W_{t-1} L_{t-1}-T_{t}+R_{t-1} D_{t-1}
\end{aligned}
$$

where $C, L, D, T$ stand for consumption, labor supply, deposits in banks and tax, respectively. $P, W, R$ are final good prices, nominal wage and gross nominal interest on banks' deposits. $\beta, \varphi, \chi>0$, in addition $\beta<1$. Note that the contract for labor is set one period in advance, that is at period $t$ households and firms decide on labor for the period $t+1$ and the next period's wage is determined by the market at period $t$.

Bank deposits are guaranteed by the government, which in the case of bank insolvency pays the deposits and interest to the household.

first-order conditions are the following:

$$
\begin{gathered}
{\left[C_{t}\right] \frac{\partial U_{t}}{\partial C_{t}}=\frac{1}{P_{t} C_{t}}} \\
{\left[L_{t}\right] \beta E_{t}\left[\frac{W_{t}}{P_{t+1}} \frac{1}{C_{t+1}}-\chi L_{t-1}^{\varphi}\right]=0} \\
\Omega_{t, t+1}=\beta \frac{C_{t}}{C_{t+1}} \\
{\left[D_{t}\right] E_{t} \Omega_{t, t+1} \frac{P_{t}}{P_{t+1}} R_{t}=1}
\end{gathered}
$$

where $\Omega_{t, t+1} i$ is stochastic discount factor. first-order conditions state that the marginal disutility from labor is equalized to the marginal utility of consumption and that the nominal return on money holding should on the margin compensate the consumer for postponing consumption to the next period.

Capital Producing Firms Capital good producers are competitive firms. They use units of the intermediate good to produce capital with unit marginal costs. They also buy depreciated capital and renovate it with unit marginal costs.

$$
\max _{I_{t}}\left(Q_{t} I_{t}-I_{t}\right)
$$


where $I_{t}$ is investment and $Q_{t}$ is the price of capital. The first-order conditions imply that:

$$
\left[I_{t}\right]: Q_{t}=1
$$

Final Good Producers (retailers) Retailers combine output from intermediate good producers using production function:

$$
Y_{t}=\left[\int_{0}^{1} Y_{f t}^{\frac{\varepsilon-1}{\varepsilon}} d f\right]^{\frac{\varepsilon}{\varepsilon-1}}
$$

where $Y_{f t}$ is the output from retailer $f$ and $\varepsilon$ is elasticity of substitution. Firms are monopolistic competitors, who solve the following problem:

$$
\max _{P_{f t}^{*}} \sum_{i=0}^{\infty} \gamma^{i} \Omega_{t, t+i}\left[\frac{P_{t}^{*}}{P_{t+i}} \prod_{k=1}^{i}\left(1+\pi_{t+k-1}\right)-P_{m, t+i}\right] Y_{f t+i}
$$

subject to demand from households

$$
Y_{f t}=\left(\frac{P_{t}^{*}}{P_{t}}\right)^{-\varepsilon} Y_{t}
$$

where $P_{t}^{*}$ is the optimal price set in period $t, \gamma$ is the fraction of firms which cannot reset their prices but only index by inflation, and $\pi_{t}=\frac{P_{t}}{P_{t-1}}-1$ is a one period inflation rate.

The problem results in the first-order condition:

$$
\sum_{i=0}^{\infty} \gamma^{i} \Omega_{t, t+i}\left[\frac{P_{t}^{*}}{P_{t+i}} \prod_{k=1}^{i}\left(1+\pi_{t+k-1}\right)-\mu P_{m, t+i}\right] Y_{f t+i}=0
$$

where $\mu \equiv \frac{1}{1-\frac{1}{\varepsilon}}$

and price dynamic: 


$$
\begin{gathered}
P_{t}=\left[\int_{0}^{1} P_{f t}^{\frac{1}{1-\varepsilon}} d f\right]^{1-\varepsilon} \\
P_{t}=\left[(1-\gamma)\left(P_{t}^{*}\right)^{\frac{1}{1-\varepsilon}}+\gamma\left(\left(1+\pi_{t-1}\right) P_{t-1}\right)^{\frac{1}{1-\varepsilon}}\right]^{\varepsilon-1}
\end{gathered}
$$

Government The government collects lump-sum taxes from households, transfer lump-sum subsidies to households and takes money in reserves, $N_{t}$, such that the government's budget constraint is satisfied:

$$
G_{t}+R_{t}^{N} N_{t-1}=T_{t}+N_{t}
$$

The government also functions as a central bank and conducts monetary policy according to the rules:

$$
i_{t}=\left(1-\rho_{i}\right)\left(\bar{\imath}+\iota_{\pi} \pi_{t}+\iota_{y}\left(\log Y_{t}-\log Y_{t}^{*}\right)\right)+\rho_{i} i_{t-1}+\epsilon_{t}
$$

where $Y^{*}$ is natural output, defined in appendix B.

Equilibrium To close the model the following market clearing conditions and a resource constraint have to hold.

The capital market clears:

$$
K_{t}=\sum_{h} S_{t}^{h}
$$

the interbank market clears:

$$
\sum_{h} B_{t}^{h, i}=0
$$

the government's budget constraint is satisfied:

$$
G_{t}+R_{t-1}^{N} N_{t-1}=T_{t}+N_{t}
$$

the aggregate resource constraint holds:

$$
C_{t}+K_{t}-(1-\delta) \zeta_{t} K_{t-1}+G_{t}=Y_{t}
$$


and supply equals demand on deposits and labor markets.

Then, equilibrium is defined as a set of allocations: $C_{t}, D_{t}, L_{t}, K_{t},\left\{S_{t}^{h}\right\}^{H}$, $\left\{N_{t}^{h}\right\}^{H}, G_{t}$ such that given prices $P_{t}, W_{t}, R_{t}, R_{t}^{N}, R_{t}^{i}, R_{k, t+1}, P_{m t}$, past choices

$\left\{L_{t-1}, D_{t-1}, K_{t-1},\left\{S_{t-1}^{h}\right\}^{H},\left\{N_{t-1}^{H}\right\}^{H}\right\}$, and current realization of $\zeta_{t}$ and the belief system, all agents solve their problems and all markets clear.

\section{Simulation}

We simulate the model log-linearized around the steady state ${ }^{9}$. We consider the steady state with heterogeneous agents, but constant moments of belief distribution and market uncertainty. Steady-state government expenditures are assumed to be zero (that is, in the steady state all banks are solvent). We focus on the subset of solutions where interest rates on reserves and on interbank credit are equal. The equality of the two interest rates guarantees that banks have no incentives to borrow on the interbank market to invest in the reserves.

In the following section we present the model's responses to sentiment and fundamental shocks. We then simulate the model with calibrated shocks to compare the model's dynamics with the data. Finally, we simulate the crisis and consider a stylized analogue of credit support policy.

\subsection{Calibrated Parameters}

The calibrated parameter values are described in table 1. Most of the parameters are standard with the values taken from Gertler and Karadi (2011). The share of expert opinion in the banks' forecast is taken to be $10 \%$. The value of the parameter is only suggestive as it is not straightforward to find an empirical counterpart and alternative parameter values are analyzed later. The value of the share of expert opinion is important for quantitative model prediction, but does not affect the length of a recession. The value for the autoregressive parameter for $\zeta$ and $\mu$ is assumed to be equal to the persistence of capital quality shock in Gertler and Karadi (2011), where capital quality shock was calibrated to match the decline in effective capital stock during the crisis. The persistence of beliefs was estimated on pre-crisis data using the procedure described in appendix C.

\footnotetext{
${ }^{9}$ Simulation is done using Dynare version 4.
} 


\begin{tabular}{|l|l|l|}
\hline Parameter & Description & Value \\
\hline$\alpha$ & capital share & 0.3 \\
\hline$\delta$ & depreciation & 0.02 \\
\hline$\varphi$ & inverse Frisch elasticity of labor supply & 1 \\
\hline$\chi$ & utility weight of labor & 1 \\
\hline$\rho_{\zeta}$ & autoregressive parameter for capital quality & 0.66 \\
\hline$\rho_{\mu}$ & autoregressive parameter for shock to capital quality & 0.66 \\
\hline$\gamma$ & Calvo-pricing parameter & 0.779 \\
\hline$\varepsilon$ & elasticity of substitution & 4.167 \\
\hline$\kappa_{\pi}$ & coefficient on inflation in Taylor rule & 1.5 \\
\hline$\kappa_{y}$ & coefficient on output in Taylor rule & 0.125 \\
\hline$\rho_{i}$ & persistence parameter in Taylor rule & 0.8 \\
\hline$\rho$ & banks' risk aversion & 2 \\
\hline$s$ & share of economic forecast in belief formation & 0.9 \\
\hline$\rho_{\theta}$ & persistence of expert opinion & 0.61 \\
\hline$\rho_{\sigma r}$ & persistence of uncertainty shock & 0.7 \\
\hline$\rho_{\sigma \zeta}$ & persistence of shock to belief diversity & 0.33 \\
\hline
\end{tabular}

Table 1: Calibrated Parameter Values

To model the sentiment shocks: shock to average market belief, shock to diversity of experts' beliefs, and shock to market volatility, we use the following data series. For the average market belief we use the Ifo world economic climate for the Euro area, series "R3 : Expectations next 6 months". For the diversity of expert opinions, measured as standard deviation, we use the Survey of Professional Forecasters, conducted by the ECB, series "Real GDP growth, based on standardized ESA definition", forecast for the next two quarters. Finally, for the volatility measure we use VIXX index by CBOE. We estimate the crisis shocks as deviation from the pre-crisis trend in the 4th quarter of 2008, when most of the variables displayed the highest deviation. The detailed procedure to estimate the shocks is described in appendix C. The shock values are given in table 2 .

We acknowledge that neither our shock estimation procedure nor the choice of empirical counterpart may precisely capture market sentiment during the onset of the recent financial crisis. However, we believe they serve as a reasonable proxy for modelling market expectations during that period. 


\begin{tabular}{|l|l|l|}
\hline Shock to model variable & Empirical counterpart & $\begin{array}{l}\text { Estimated de- } \\
\text { viation }\end{array}$ \\
\hline $\bar{E}_{t} \hat{\zeta}_{t+1}$ & $\begin{array}{l}\text { Expectation of Business Cli- } \\
\text { mate over next } 6 \text { months } \\
\text { (Ifo) }\end{array}$ & -0.76 \\
\hline$\sigma_{\hat{R}}$ & VIXX & 0.32 \\
\hline$\sigma_{\hat{\zeta}}$ & SPF (ECB) & 0.2 \\
\hline banks' budget constraint & $\begin{array}{l}\text { Increase in ECB's balance } \\
\text { sheet }\end{array}$ & 0.29 \\
\hline
\end{tabular}

Table 2: Calibrated Sentiment Shocks

\subsection{Role of Sentiment Shocks}

First, consider the impulse responses to pure "sentiment shocks". These are shocks that only affect market sentiment without any fundamental reason for the sentiment to change. In our model these sentiment shocks consist of a shock to average expert opinion, $\bar{\varepsilon}_{t}^{\eta}$, uncertainty shock, $\sigma_{\hat{R}}$, and a shock to the diversity of expert opinions, $\sigma_{\zeta}$. As was suggested in the literature, these shocks alone could be responsible for economic fluctuations - cycles of booms and busts. In what follows we simulate the model and report the impulse response functions with respect to a 0.05 standard deviation in sentiment and fundamental shocks.

The upper set of graphs in figure 4 (paneles a and b) shows the impulse responses to a negative expert opinion shock and the lower set of graphs - to an uncertainty shock. When the average market belief about tomorrow's return drops, it generates a decline in output $(y)$, consumption $(c)$, investment $(i n v)$, deposit interest rate $(r)$ and a persistent drop in the amount of credit to real sector $(k)$. Because interbank lending was modeled as risk-free (being in fact one of the safe assets), a decline in average bank sentiment results in a higher interbank credit supply (lend) and a lower safe asset interest rate $(r n)$. The amount of money kept in reserves $(n)$ goes up as the demand for interbank loans is constrained by the number of optimists and by the collateral constraint.

When the uncertainty shock hits (figure 4, panels c and d), it is more difficult for bankers to predict future return. We interpret a rise in uncertainty as an increase in the market volatility index. The reaction of the model economy to an uncertainty shock is similar to that observed in the real economy, i.e. a persistent drop in output 
and consumption, and a freeze on the interbank market. In our model, however, the freeze on the interbank market is explained by the lower demand for interbank loans due to poor investment perspectives. In reality, a lower supply of interbank credit due to increased counterparty risk and liquidity concerns was also an important factor. Model responses to both of the shocks in figure 4 indicate a flight to safety (an increase in interbank lending and reserves, $n$ ).

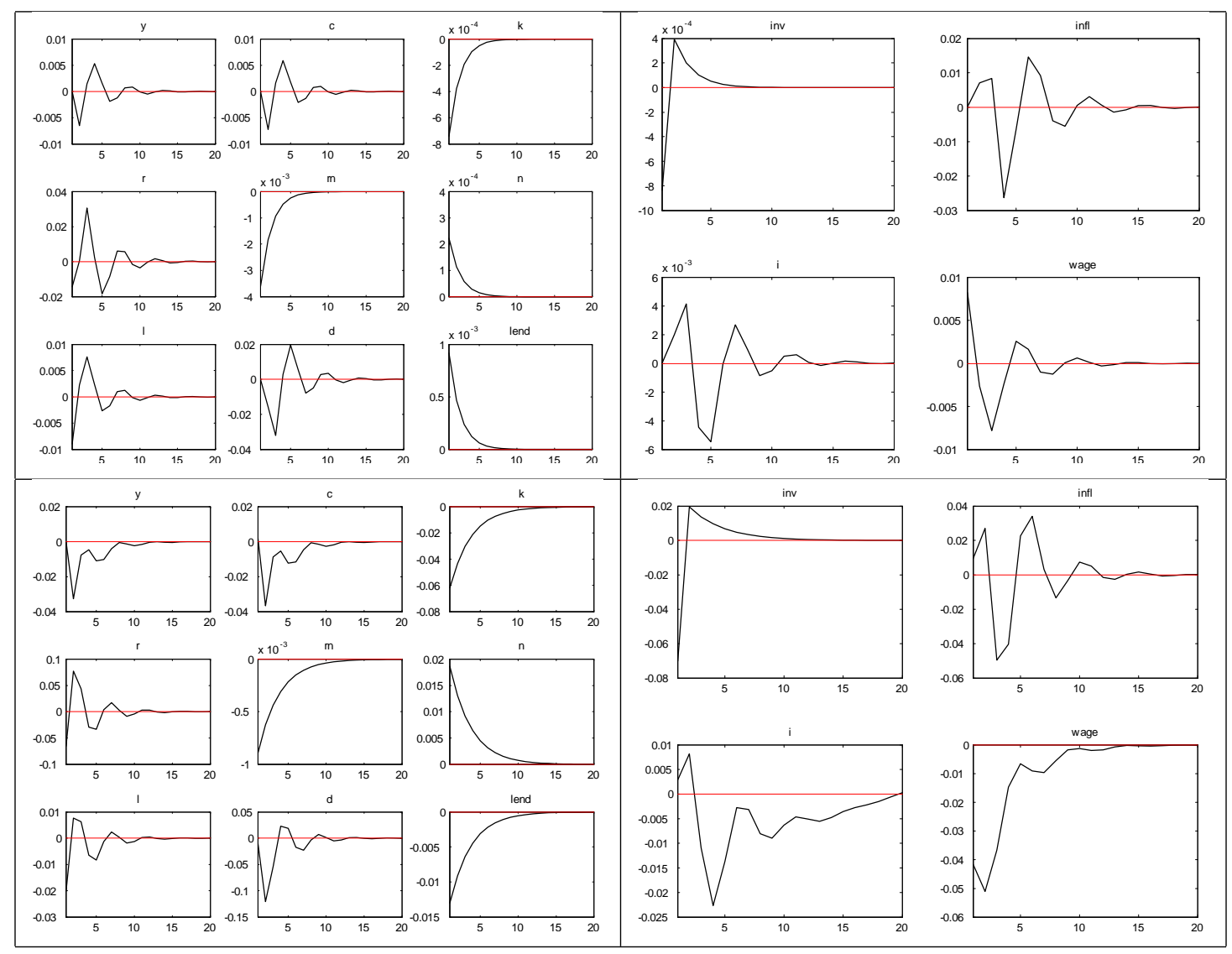

Figure 4: Impulse Responses to 0.05 Belief and Volatility Shocks

Notes: panels a and b report responses to a negative expert opinion shock; $\mathrm{c}$ and $\mathrm{d}$ to a positive volatility shock. The following notation applies: y-output, c-consumption, k- capital, r -deposit interest rate, $\mathrm{rn}$ - safe asset interest rate, $\mathrm{n}$ - amount of reserves, l-labor supply, lend - interbank loans, inv - investment, infl - inflation, i - nominal interest rate, d - deposits, wage - wage

Figure 5 captures impulse response functions to an increase in the diversity of expert opinions $\left(\sigma_{\zeta}\right)$. An increase in the diversity of expert opinions leads to a higher supply of interbank credit, lend, which alone generates a rise in output, in credit to the real economy and consumption. This model reaction predicts that belief diversity 
drives asset price boom, which in our stylized model is overinvestment. Impulse responses also indicate how important heterogeneity of beliefs is when considering an economy's dynamics or reaction to a policy.

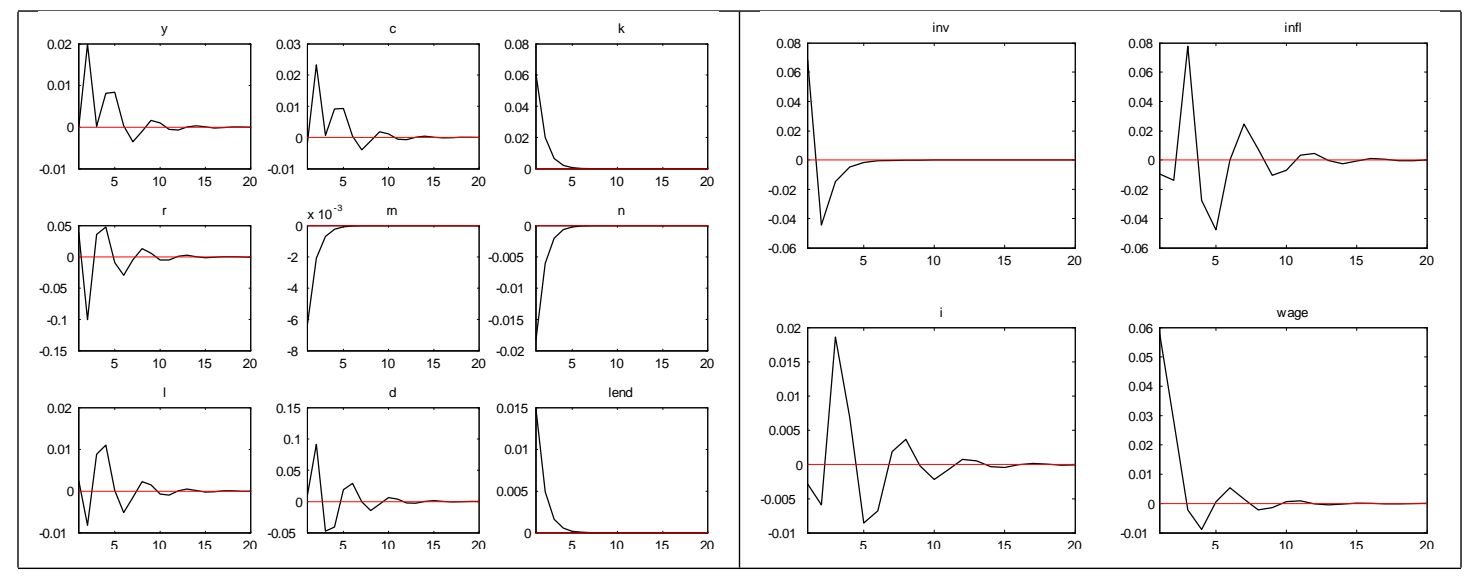

Figure 5: Impulse Responses to 0.05 Increase in Belief Diversity

Note: the following notation applies: y-output, c -consumption, k- capital, $\mathrm{r}$-deposit interest rate, $\mathrm{rn}$ - safe asset interest rate, $\mathrm{n}$ - amount of reserves, l-labor supply, lend - interbank loans, inv - investment, infl - inflation, i - nominal interest rate, $\mathrm{d}$ - deposits, wage - wage

Thus, figures 4 and 5 illustrate the role of expectations in the model economy. Without any fundamental reason, a change in banks' sentiment, or a measure of their agreement on the forecast or change in market volatility, generate a prolonged depression or a boom. We acknowledge that model variables overreact to sentiment shocks, though the length of reaction is still comparable to the crisis observed in the data. This is due to a simplified model structure, where the amount of capital in the economy has to be refinanced each period and, therefore, is heavily dependent on banks' expectations. Introducing the other sources of capital financing, e.g. internal financing of the firms would complicate the model but would not change its implications qualitatively.

Our findings about the importance of sentiment shocks are in line with recent empirical and theoretical work. Among the empirical papers, Bloom (2009) and Beaudry et al. (2011) find that sentiment shocks are important factors in generating volatility in economic variables. Bloom (2009) presents evidence that uncertainty shocks (identified as stock market volatility index) translate into volatility of output and hours worked. Beaudry et al. (2011) use a sign-restrictions approach to shock identification in a SVAR model and conclude that an optimism shock accounts for 
over $50 \%$ of forecast variation in hours worked. Among the theoretical models, work by Beaudry et al. (2011), Lorenzoni (2009), Milani (2011) and Fujiwara et al. (2011), emphasize the importance of imperfect information and noisy beliefs. Bullard et al. (2010) show that noisy expert adjustments result in "exuberance" equilibria even in situations when rational expectation equilibrium is determinate. Because the model is log-linearized around the steady state, we do not account for non-linear and asymmetric effects that move a model from the initial steady state. Even close to the steady state the model exhibits rich dynamics in response to sentiment shocks.

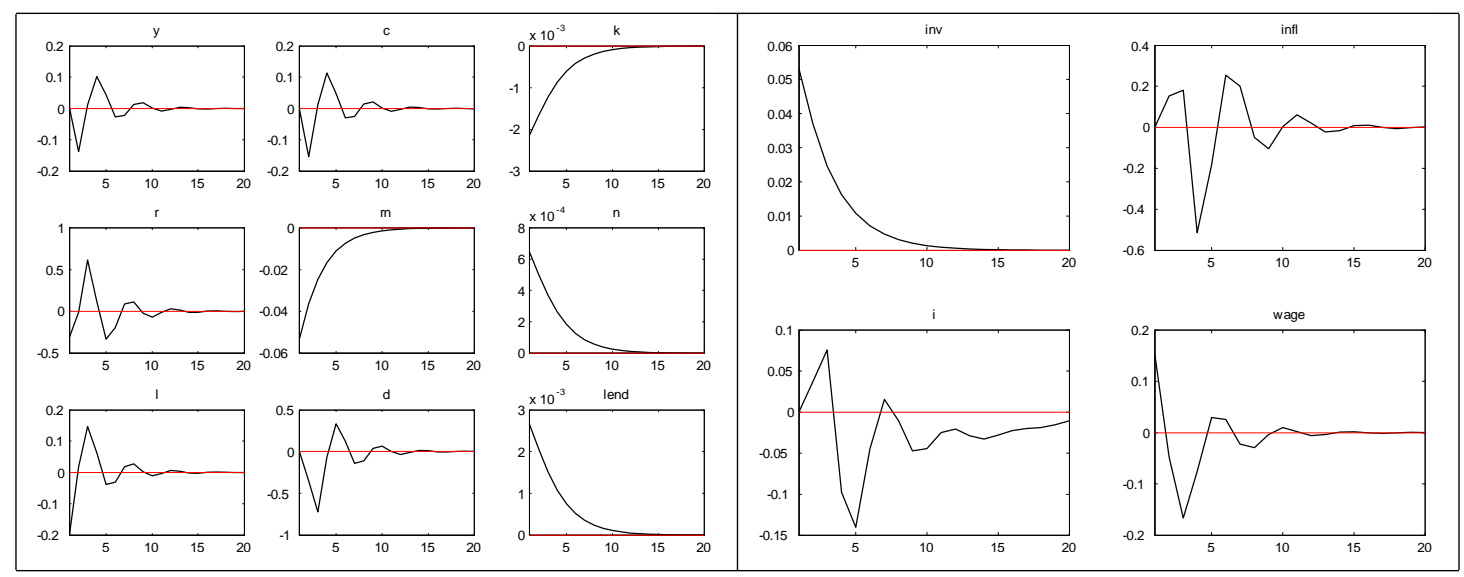

Figure 6: Impulse Responses to 0.05 Fundamental Shock

Note: the following notation applies: y-output, c -consumption, k- capital, $r$-deposit interest rate, rn - safe asset interest rate, n - amount of reserves, l-labor supply, lend - interbank loans, inv - investment, infl - inflation, i - nominal interest rate, $\mathrm{d}$ - deposits, wage - wage

Now consider the model's response to a fundamental shock - a shock to capital quality, $\zeta_{t}$ (figure 6). Because the agents learn about the shock, a drop in $\zeta_{t}$ results in a drop in average market belief about $\zeta_{t+1}-\bar{E}_{t} \hat{\zeta}_{t+1}$. At the same time, as there are no expectational shocks agents forecast future values of $\zeta_{t}$ rationally (i.e. there is no noise in expert opinions). That is, when a fundamental shock hits, it reduces the value of the capital exogenously, but agents understand the nature of the crisis and rebuild the capital stock (investment goes up). Comparing the magnitude of a recession caused by fundamental and sentiment shocks, it could be suggested that in an economy where the real sector depends on credit, investor sentiment is as important a driving force as fundamental factors. That is why any policy relevant model which ignores market sentiment may fail to predict the economy's reaction in times of downturn or to foresee the forthcoming crisis. 


\subsection{Pre-crisis Dynamics of the Model}

Having calibrated the model, we first simulate the it without crisis to compare its dynamics with pre-crisis economy. For the shock deviation, we use the standard deviation of the innovations ${ }^{10}$ estimated on the pre-crisis period . Due to oversimplification on the real side, the model predicts much higher volatility of the variables of interest than is observed in the data. This is caused, in particular, by the following assumptions. The first is that firms have to reinvest into capital every period. That is, they issue one period claims only. The second is that banks are the only source of financing in the economy. These two assumptions simplify the asset structure, but result in the extreme dependence of firms on bank credit and sentiment. The volatility of banks expectations then translates into the volatility of output, credit and investment.

In table 3 we compare the standard deviation of the variables of interest with their empirical counterparts ${ }^{11}$.

\begin{tabular}{|l|l|l|}
\hline & Model prediction & Data prediction \\
\hline output $(\mathrm{y})$ & 0.052 & 0.004 \\
\hline credit $(\mathrm{k})$ & 0.125 & 0.034 \\
\hline investment $(\mathrm{i})$ & 0.164 & 0.110 \\
\hline
\end{tabular}

Table 3: Standard Deviation of Simulated Variables and their Empirical Counterparts

As table 3 illustrates, the model's reaction to sentiment shocks is several times stronger than that observed in the data. Keeping in mind this excessive volatility, we next consider the model's reaction to a fundamental shock of the same magnitude together with the calibrated values for sentiment shocks. This exercise helps us assess which of the factors might play a bigger role in generating the crisis, and compare the observed crisis dynamics with the model's prediction.

\footnotetext{
${ }^{10}$ The model was simulated 10000 times.

${ }^{11}$ For estimation of standard deviation of empirical counterparts, we use the same model as for the shock estimation. For details, see appendix C.
} 


\subsection{Crisis Simulations}

To simulate a crisis we consider the following shocks: a drop in average expert opinion, an increase in experts' uncertainty and in the dispersion of experts' beliefs, and a drop in capital quality (which also represents a shock to the value of the capital). That is, we model a crisis as the combination of a drop in return on capital together with investors' overpessimism and a panic among them.

To calibrate realistic values of the magnitude and persistence of expectational shocks we use the empirical counterparts described in table 2. As it is not straightforward to calibrate a capital quality shock, we use the value of 0.05 as in Gertler and Karadi (2011).

Figure 7 shows impulse response functions to expectational shocks of the magnitude described in table 2 and to a capital quality shock. The trigger of the crisis in our model is a drop in capital quality (and implicitly in collateral value) combined with increased pessimism among investors. Such a crisis causes an initial drop in capital and investment, output on the $0.27,0.25$, and 1.2 accordingly. The drop in capital is persistent and lasts for about 2 years. Without having any friction on the capital producers' side, we do not aim to match the persistence of investment response.

With bankers pessimistic about risky asset, the demand for safe assets increases. The two safe assets in this economy are interbank loans and bank reserves. With bankers less willing to invest into risky asset and having enough funding opportunities, the equilibrium safe asset interest rate drops. Poor credit opportunities for manufactureres result in lower demand for labor, though this is partially offset by the substitution between the two inputs. The deposit interest rate falls as there is less demand for funds from banks. These drive the deposits down even more as households become less wealthy. The desire of households to restore their consumption level explains an increase in labor supply and reversal in responses except for capital, reserves and interbank loans, which are driven by persistent expert opinions. Introducing learning for households would smooth the model responses. Note that without expectational shocks (see figure 6), a shock to capital quality alone does not generate such strong and prolonged recession. 


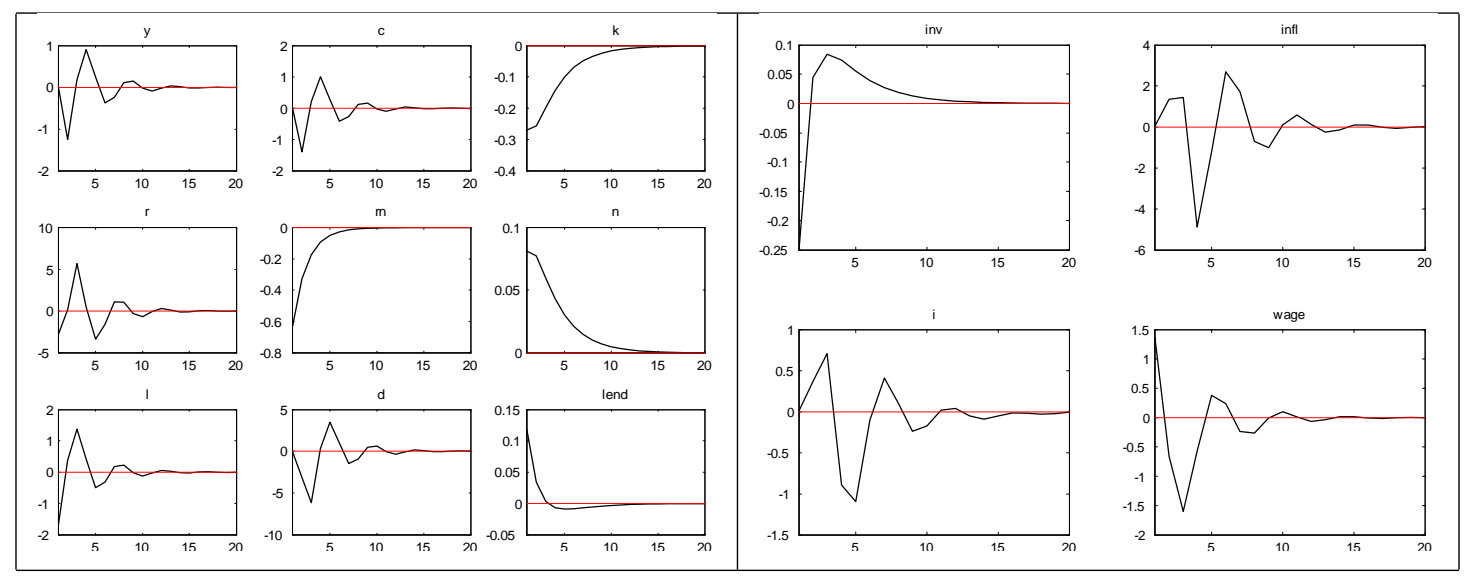

Figure 7: Crisis Simulation

Note: the following notation applies: $y$-output, c -consumption, k- capital, $r$-deposit interest rate, rn - safe asset interest rate, n - amount of reserves, l-labor supply, lend - interbank loans, inv - investment, infl - inflation, i - nominal interest rate, $\mathrm{d}$ - deposits, wage - wage

In the next subsection we compare the model's responses with their empirical counterparts.

\subsection{Policy Experiment}

Having simulated the crisis, we consider a simplified version of the policy measures implemented by the major central banks. In our framework, the credit support policy may be represented as a shock to banks' budget constraint. The "policy" shock is calibrated as an increase in the ECB's balance sheet (see appendix C for details).

Figure 8 shows the response to a crisis simulation with liquidity provision (solid line) and without (dotted line). The basic assumption is that the policy does not influence banks' expectations and is not taken by the market as a signal. Under this assumption, the policy mitigates the magnitude of the crisis slightly, but does not stop it or shorten it. Compared to the situation without policy, reserves increase significantly, capturing the observation that the funds provided to banks were partially allocated to safe assets or kept in reserves. Note that by the construction of the model, banks do not have incentives to keep in reserves funds borrowed on the interbank market; that is, the increase in reserves is driven by funds provided by the 
central bank. ${ }^{12}$ An increased demand for safe assets drives the safe asset interest rate down.

Table 4 summarizes the model's response and compares it to the change in the euro area's empirical counterparts during the financial crisis ${ }^{13}$. It can be seen from the table that in general the model captures the observed behavior of investment and capital, though overestimates the initial decline of output to a simplified model structure. Mainly this is because firms are forced to refinance capital each period and banks are the only source of funds in the economy. Though overestimated, the model's responses have realistic duration and dynamics where a decline in credit to the real sector is concerned.

\begin{tabular}{|l|l|l|l|l|}
\hline $\begin{array}{l}\text { Model } \\
\text { vari- } \\
\text { able }\end{array}$ & $\begin{array}{l}\text { Simulation with- } \\
\text { out policy }\end{array}$ & $\begin{array}{l}\text { Simulation with } \\
\text { policy }\end{array}$ & Empirical counterpart & $\begin{array}{l}\text { Observed } \\
\text { log- } \\
\text { deviation }\end{array}$ \\
\hline$y$ & -1.255 & -1.037 & Real GDP & -0.05 \\
\hline$k$ & -0.269 & -0.224 & Loans Up To 1 Year & -0.2 \\
\hline inv & -0.249 & -0.198 & $\begin{array}{l}\text { Gross Fixed Capital } \\
\text { Formation }\end{array}$ & -0.3 \\
\hline
\end{tabular}

Table 4: Response to the Crisis by Model Variables and their Empirical Counterparts

That is, in our model such a policy, absent any costs of its implementation, helps to decrease the recession, yet without influencing the expectations, it is not able to stop the crisis nor decrease its duration. The most significant impact of the policy is on reserves amount, which are twice as high under the policy provision. Our finding that policy had a mitigating effect on crisis depth is in line with the studies of Gertler and Karadi (2011), Gertler and Kiyotaki (2010), and Negro et al. (2011), though we emphasize a different financial friction. As in these studies, we find that the duration of crisis is unaffected by the policy.

Our model captures the "hoarding" behavior of the banks. That is, with the expectations taken into account, the model captures the observed behavior of the banks, who were holding some of the amount of liquidity provided by the central banks or investing it into liquid assets. In our model this inefficiency can be assessed as an increase in capital investment relative to an investment into a safe asset, or

\footnotetext{
${ }^{12}$ The model does not capture the design of liquidity provision (i.e. auction) and all banks, independent of their willingness to invest, receive the same amount of funds.

${ }^{13}$ The data description is in appendix $\mathrm{C}$.
} 


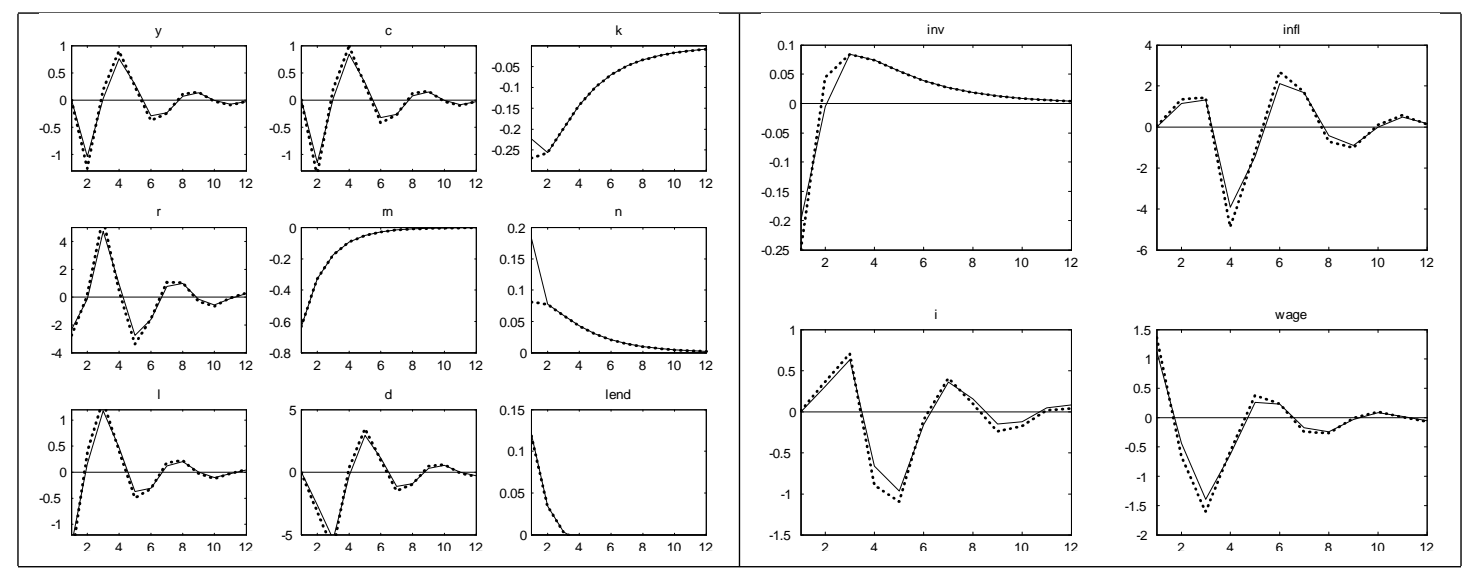

Figure 8: Response to Crisis with Liquidity Provision

Notes: baseline - impulse responses with liquidity provision, dotted line - without liquidity provision The following notation applies: $\mathrm{y}$-output, c -consumption, $\mathrm{k}$ - capital, $\mathrm{r}$-deposit interest rate, $\mathrm{rn}$ - safe asset interest rate, $\mathrm{n}$ - amount of reserves, l-labor supply, lend - interbank loans, inv - investment, infl - inflation, i - nominal interest rate, d - deposits, wage - wage

an increase in reserves when banks' balance sheets are enhanced by the central bank's money. To see what drives the hoarding behavior in our model and why the expectations play an important role there, compare the coefficients in policy functions for the components of the crisis:

$$
\left(\begin{array}{c}
\hat{c}_{t} \\
\hat{k}_{t} \\
\hat{n}_{t}
\end{array}\right)=A\left(\begin{array}{c}
\sigma_{\hat{R}, t} \\
\sigma_{\zeta t} \\
\bar{\varepsilon}_{t}^{\eta} \\
v_{t} \\
\text { policy }
\end{array}\right)+B X_{t}
$$

where $A$ is 3 by 5 matrix, with the elements reflecting the coefficients on sentiment shocks $\left(\sigma_{\hat{R}, t}, \sigma_{\zeta t}, \bar{\varepsilon}_{t}^{\eta}\right)$, on the fundamental shock, and on the policy shock, $X_{t}$ contains all the other state variables and shocks, and $B$ is a matrix of corresponding coefficients. The change in $n$ relative to $k$ on the crisis event is then given by (keeping $X_{t}$ unaffected by contemporaneous crisis and policy shocks): 


$$
\begin{aligned}
\Delta \hat{n}_{t}-\Delta \hat{k}_{t}= & \underbrace{\left(a_{31}-a_{21}\right)}_{1.611593} \sigma_{\hat{R}, t}+\underbrace{\left(a_{32}-a_{22}\right)}_{-1.573016} \sigma_{\zeta t}+\underbrace{\left(a_{33}-a_{23}\right)}_{0.019271} \bar{\varepsilon}_{t}^{\eta}+ \\
& +\underbrace{\left(a_{34}-a_{24}\right)}_{0.055761} v_{t}+\underbrace{\left(a_{35}-a_{25}\right)}_{0.194376} \text { policy }_{t}
\end{aligned}
$$

Equation (44) illustrates the relative importance of the shocks in stimulating the hoarding behavior of banks. Those having the strongest impact are the uncertainty shock $\left(\sigma_{\hat{R}, t}\right)$ and shock to the diversity of experts' opinions $\left(\sigma_{\zeta t}\right)$. If the latter stimulates investment into risky asset through increased supply of credit on the interbank market, the former reduces the incentives of risk-averse banks to engage in risky activities. The shock to average market expectations shifts investors' preferences towards safe assets, with an increased activity on the interbank market compensating for lowering of the average expected return. The fundamental shock in our model, $v_{t}$, lowers the expected future return of the capital (see (13)), with some of the investment relocating towards the safe asset. The pure shock to the banks' balance sheet $($ policy $)$, i.e. without fundamental and expectational shocks, is allocated among safe and risky assets with a higher share of a safe asset. The difference in the coefficients $\left(a_{35}-a_{25}\right)$ in front of the policy shock in equation (44) reflects the hoarding behavior driven by the banks' preferences and information structure of the model. It reflects the share of the central bank's provided liquidity, which is not used to stimulate the economy. In other words, it reflects a measure of policy inefficiency.

Within the framework of the model, we can calculate what should be the amount of liquidity provided to restore the variables of interest towards their steady state level, given the crisis- i.e. the realized values of expectational and fundamental shocks described in table 2. Assuming that the policy maker is interested in restoring consumption, consider the policy function for $\hat{c}_{t}$ in equation (43). The drop in consumption caused by the crisis is then given by:

$$
\Delta \hat{c}_{t}=a_{11} \sigma_{\hat{R}, t}+a_{12} \sigma_{\zeta t}+a_{13} \bar{\varepsilon}_{t}^{\eta}+a_{14} v_{t}+a_{15} \text { policy }
$$

Setting the right hand side of the equation to zero (so that consumption stays 
at the steady state level), we get:

$$
\text { policy }_{t}=-\frac{1}{a_{15}}\left(a_{11} \sigma_{\hat{R}, t}+a_{12} \sigma_{\zeta t}+a_{13} \bar{\varepsilon}_{t}^{\eta}+a_{14} v_{t}\right)
$$

Under our parametrization and a simplified model structure, the increase in the central bank's balance sheet should be around $122 \%$. Obviously, with the model to account for the possible costs of such a huge increase, the costs of such a policy may outweigh its benefits.

Thus, despite the fact that our stylized model overreacts to crisis shocks and its quantitative predictions are overestimated, qualitatively it captures the behavior of investors observed during the crisis, and reflects the hoarding behavior of banks, both often missing in the similar literature. The policy analysis here illustrates our point made earlier about the importance of credit friction on the financial sectorproducer side, as well as investor sentiment. Bankers' risk aversion, together with their imperfect information leads them to hoard some of the funds transferred from central banks, causing low policy efficiency and explaining inability of the central banks to restore market functioning at the onset of the financial crisis. Clearly, to consider the policy effect quantitatively, one needs to extend the model by the standard set of frictions and study the possible choices of sentiment shock identification.

\subsection{Sensitivity to Parameter Values}

In this section we vary the key parameters of the model to consider how its dynamics is affected by the parameter values. The parameters expected to have a comparatively large influence on the results are risk aversion of the banks and share of expert opinion in the final forecast.

We consider two alternative values for the share of expert adjustments in the banks' final forecasts: 0.05 (low) and 0.2 (high). For the risk-aversion parameter we study the change in the model's dynamics when investors are $10 \%$ more and $10 \%$ less risk averse as compared to a baseline specification, that is $\rho=2.2$ and $\rho=1.8$. The key dynamics characteristics are presented in table 5 , and the impulse responses of the variables of interest are in appendix D.

As table 5 illustrates, an economy populated by more risk-averse agents suffers less during the crisis, than does an economy with less risk-averse investors. This 
result is straightforward, as agents invest less in a risky asset and therefore lose less when the value of the risky asset falls. Concerning the share of expert opinion, the agents are better off putting more weight on the econometric forecast. On the one hand this forecast does not take into account information about future changes obtained from the news. On the other side hand, the econometric forecast does not contain noise coming from expert interpretation of the news. As can be seen from table 5 , the latter effect dominates. The model with a higher share of expert opinion shows a deeper recession. In our model, however, this comes from the construction, where the crisis is modelled by a series of shocks, including a shock to expert opinion. With a higher share of expert opinion in the banks' forecasts, this negative shock has a larger impact on their investment decisions. The larger the investors' overpessimism, the deeper the recession.

The baseline model predictions are in the middle of the symmetrical alternatives (see table 3).

\begin{tabular}{|l|l|l|l|l|}
\hline parameter & $\begin{array}{l}\text { change } \\
\text { in output } \\
\text { in crisis } \\
\text { period }\end{array}$ & $\begin{array}{l}\text { change } \\
\text { in output } \\
\text { with policy }\end{array}$ & $\begin{array}{l}\text { change } \\
\text { in capital } \\
\text { in crisis } \\
\text { period }\end{array}$ & $\begin{array}{l}\text { change } \\
\text { in capital } \\
\text { with policy }\end{array}$ \\
\hline high $\rho$ & -1.2389 & -1.0227 & -0.2326 & -0.1923 \\
\hline low $\rho$ & -1.2775 & -1.0564 & -0.3175 & -0.2666 \\
\hline $\begin{array}{l}\text { high share } \\
\text { of expert } \\
\text { adjust- } \\
\text { ment }\end{array}$ & -2.2401 & -2.0218 & -0.38125 & -0.3362 \\
\hline $\begin{array}{l}\text { low share } \\
\text { of expert } \\
\text { adjust- } \\
\text { ment }\end{array}$ & -0.7631 & -0.5447 & -0.2131 & -0.16807 \\
\hline
\end{tabular}

Table 5: Simulation with Alternative Parameter Values

As table 5 and figures 9 and 10 in appendix D illustrate, the choice of parameters influences the model dynamics slightly, but does not change the main predictions or the duration of shock effects. 


\section{Concluding Remarks and Future Work}

Agents' expectations have proved to be an important factor in generating economic fluctuations. This paper develops a model of an economy, whose dynamics is driven not only by fundamentals, but also by the moments of credit market expectations. Simulations suggest that shocks to investors' expectations generate swings in the economy as large as shocks to fundamentals. The reason for this is the dependence of the real economy on credit. That is, expectational shocks affect the real economy, and in turn, reduce the investors' wealth. This results in smaller credit supply and deeper recession. The model framework captures this relationship by having a banking sector populated by investors with heterogeneous beliefs. Heterogeneity of beliefs gives rise to an interbank market and overinvestment. The moments of bankers' beliefs and their perceived uncertainty are then treated in the model as state variables, yielding a model as tractable as many DSGE models in the literature.

With the beliefs' shocks of a magnitude observed during the recent financial turmoil, the model produces a response comparable to the real crisis in terms of GDP and investment. With a model to simulate the crisis, we consider the question of policy effects. We conduct a simple exercise to mimic the key moment of liquidity provision policy - enhancement of banks' budget constraint. The result is intuitive and mirrors the outcome of empirical studies, namely that such a policy mitigates the magnitude of the crisis, however, does not prevent a depression nor decrease its duration. Unlike similar studies, our model captures the banks' hoarding behavior observed during the crisis, which is believed to lower policy efficiency. Just as their real life prototypes, banks in our model hoard the funds obtained from central banks as the volatility of returns increases and they become overpessimistic about returns in the real sector.

The current model, however, performs poorly when mimicking the data, especially output. One reason for this is its simplified structure, in which firms are restricted to buying capital every period and their ability to attract funds depends heavily on bankers' sentiment. An obvious extension of the model is then to introduce an alternative source of financing for manufacturers. Then, the propagation of the sentiment shocks to output would be limited and would be closer to its empirical counterpart. Another shortcoming of the model's structure is primitive learning by banks and rational expectations by other sectors of the economy. Introducing more 
robust learning and imperfect expectations for other model sectors would make for a more realistic structure and result in smoother responses by households and manufacturers. An obvious extension to the policy question tackled here is to consider the signaling effect of monetary policy. That is, the liquidity provision could be understood by banks as a signal about future states of the economy. Then, the policy could be considered more efficient in mitigating crisis, provided that there is evidence that agents react positively to central bank policy announcements.

\section{References}

Avouyi-Dovi, S. and J. Idier (2011). The impact of unconventional monetary policy on the market for collateral: The case of the French bond market. Working Paper Series 339, Banque de France.

Beaudry, P., D. Nam, and J. Wang (2011). Do mood swings drive business cycles and is it rational. NBER Working Paper Series 17651, National Bureau of Economic Research, Inc.

Bloom, N. (2009). The impact of uncertainty shocks. Econometrica r7(3), 623685.

Boz, E. and E. G. Mendoza (2010, May). Financial innovation, the discovery of risk, and the U.S. credit crisis. NBER Working Papers 16020, National Bureau of Economic Research, Inc.

Bullard, J., G. Evans, and S. H. Seppo (2010). A model of near-rational exuberance. Macroeconomic Dynamics 14(2), 166-188.

Christensen, J. H. E., J. A. Lopez, and G. D. Rudebusch (2009). Do central bank liquidity facilities affect interbank lending rates? Working Paper Series 2009-13, Federal Reserve Bank of San Francisco.

Curdia, V. and M. Woodford (2011). The central-bank balance sheet as an instrument of monetary policy. Journal of Monetary Economics 58(1), 54-79.

Donati, P. (2010). The effect of conventional and unconventional monetary policy on the money market spreads in the euro area. ECB Workshop on "Challenges to Monetary Policy Implementation Beyond the Financial Market Turbulence" 30 November - 1 December 2009. 
Fuhrer, J. (2011). The role of expectations in U.S. inflation dynamics. Working Paper Series 11-11, Federal Reserve Bank of Boston.

Fujiwara, I., Y. Hirose, and M. Shintani (2011, 02). Can news be a major source of aggregate fluctuations? a bayesian dsge approach. Journal of Money, Credit and Banking 43(1), 1-29.

Gale, D. and T. Yorulmazer (2011). Liquidity hoarding. Staff Report 488, Federal Reserve Bank of New York.

Geanakoplos, J. (2009, July). The leverage cycle. Cowles Foundation Discussion Papers 1715, Cowles Foundation for Research in Economics, Yale University.

Gertler, M. and P. Karadi (2011). A model of unconventional monetary policy. Journal of Monetary Economics 58(1), 17-34.

Gertler, M. and N. Kiyotaki (2010). Financial Intermediation and Credit Policy in Business Cycle Analysis (1 ed.), Volume 3 of Handbook of Monetary Economics, Chapter 11, pp. 547-599.

Grauwe, P. D. (2010). Top-down versus bottom-up macroeconomics. CESifo Economic Studies 56(4), 465-497.

Heider, F., M. Hoerova, and C. Holthausen (2009). Liquidity hoarding and interbank market spreads the role of counterparty risk. Working Paper Series 1126, European Central Bank.

Hilberg, B. and J. Hollmayr (2011). Asset prices, collateral and unconventional monetary policy in a DSGE model. Working Paper Series 1373, European Central Bank.

Kiyotaki, N. and J. Moore (2008). Liquidity, business cycles and monetary policy. mimeo, Princeton University and LSE.

Kurz, M. (1994, October). On rational belief equilibria. Economic Theory 4(6), 859-76.

Kurz, M. and M. Motolese (2010). Diverse beliefs and time variability of risk premia. Economic Theory $47(2), 293-335$.

Lorenzoni, G. (2009). A theory of demand shocks. American Economic Review $99(5), 2050-2084$. 
McAndrews, J., A. Sarkar, and Z. Wang (2008). The effect of the term auction facility on the London inter-bank offered rate. Staff Reports 335, Federal Reserve Bank of New York.

Milani, F. (2011). Expectation shocks and learning as drivers of the business cycle. Economic Journal 121(552), 379-401.

Negro, M. D., G. Eggertsson, A. Ferrero, and N. Kiyotaki (2011). The great escape? a quantitative evaluation of the Fed's non-standard monetary policy. Staff Reports 520, Federal Reserve Bank of New York.

Sims, C. A. (2003). Implications of rational inattention. Journal of Monetary Economics 50(3), 665-690.

Taylor, J. and J. Williams (2008). A black swan in the money market. The American Economic Journal 1(1), 58-83.

\section{Appendix}

\section{A Banks' Portfolio Choice}

Each bank solves the following problem:

$$
\begin{gathered}
\max _{\omega, \gamma} \omega_{t}^{h}\left(1+\gamma_{t}^{h}\right) E_{t}^{h} \hat{R}_{k, t+1}^{h}+\left(1-\omega_{t}^{h}\right)\left(1+\gamma_{t}^{h}\right) R_{t}^{N}-\left(1+\gamma_{t}^{h}\right) R_{t}^{i}+R_{t}^{i}- \\
-\frac{\rho \hat{\sigma}_{\hat{R}, t}^{2}\left(1+\gamma_{t}^{h}\right)^{2}\left(\omega_{t}^{h}\right)^{2}}{2} \\
\text { s.t. } \operatorname{Col}_{t} \times \omega_{t}^{h}\left(1+\gamma_{t}^{h}\right) \geq\left(1+\gamma_{t}^{h}\right) R_{t}^{i}-R_{t}^{i} \\
\omega_{t}^{h} \geq 0, \omega_{t}^{h} \leq 1
\end{gathered}
$$

where $\omega_{t}^{h}$ is a share of a firm's claims in a $h^{\prime} s$ bank budget,

$\gamma_{t}^{h}$ is a share of borrowed funds on the interbank market,

$\mathrm{Col}_{t}$ is the amount of collateral 
There are several possible cases depending on the relation between the interbank market rate and return on reserves. We concentrate on the case where the interbank market rate is equal to the return on reserves: $R_{t}^{N}=R_{t}^{i}$.

Then, depending on a bank's belief, the solution to the problem is:

\begin{tabular}{|l|c|c|}
\hline$E_{t} \hat{R}_{k, t+1}^{h}<R_{t}^{N}:$ & $\omega_{t}^{h}=0$ & $\gamma_{t}^{h}=-1$ \\
\hline & & \\
\hline$E_{t} \hat{R}_{k, t+1}^{h} \geq R_{t}^{N}:$ & $\omega_{t}^{h}=\frac{R^{i}\left(E_{t} \hat{R}_{k, t+1}^{h}-R_{t}^{N}\right)}{\operatorname{Col}_{t}\left(E_{t} \hat{R}_{k, t+1}^{h}-R_{t}^{N}\right)+R_{t}^{N} \rho \sigma_{\hat{R}, t}^{2}}$ & $\gamma_{t}^{h}=\frac{\operatorname{Col}_{t}\left(\left(E_{t} \hat{R}_{k, t+1}^{h}-R_{t}^{N}\right)\right)}{\rho \hat{\sigma}_{\hat{R}, t}^{2} R_{t}^{N}}$ \\
\hline
\end{tabular}

and the market clearing condition for the interbank market states that loan supply equals loan demand:

$$
\sum_{\left(E_{t} \hat{R}_{k, t+1}^{h} \leq R_{t}^{N}\right)} W_{t}^{h}=\sum_{\left(E_{t} \hat{R}_{k, t+1}^{h} \geq R_{t}^{N}\right)} \gamma_{t}^{h} W_{t}^{h}
$$

and the supply of bank credit to the firm equals the amount of capital in the economy:

$$
\sum_{\left(E_{t} \hat{R}_{k, t+1}^{h} \geq R_{t}^{N}\right)} \omega_{t}^{h}\left(1+\gamma_{t}^{h}\right) W_{t}^{h}=K_{t}
$$

and the amount for reserves equates the funds left from risky investment:

$$
\sum_{\left(E_{t} \hat{R}_{k, t+1}^{h} \geq R_{t}^{N}\right)}\left(1-\omega_{t}^{h}\right)\left(1+\gamma_{t}^{h}\right) W_{t}^{h}=N_{t}
$$

where $W_{t}^{h}=\Pi_{t}^{h}+\frac{D_{t}}{H}$ is banks' funds available for investment, an collateral equals the expected future value of the marginal product of capital:

$$
\operatorname{Col}_{t}=\alpha E_{t} \frac{P_{m, t+1} Y_{t+1}}{K_{t}} \equiv E_{t} m p k_{t+1}
$$

where $E_{t} m p k_{t+1}$ stands for the expected future value of marginal product of capital

and the bank's expectation of risky asset return is given by (5), (31), (13):

$$
E_{t} \hat{R}_{k, t+1}^{h}=\alpha E_{t} \frac{P_{m, t+1} Y_{t+1}}{K_{t}}+(1-\delta) E_{t}^{h} \zeta_{t+1}
$$

To derive the equilibrium values of the capital we approximate the sums with the 
integrals and use the formulas of continuous uniform distribution of banks' beliefs. As it is not straightforward to represent a bank's balance sheets as a function of its belief, we ignore wealth heterogeneity and assume that at the beginning of the period banks average their wealth. Hence, $\Pi_{t}^{h}=\frac{\sum \Pi_{t}^{h}}{H}=\Pi_{t}$ and $W_{t}^{h}=W_{t}$, Then the market clearing conditions for interbank market, capital and bank reserves take the form:

$$
\begin{aligned}
& \int_{0}^{\frac{1}{1-\delta}\left(R_{t}^{N}-m p k_{t+1}\right)} f(x) d x= \\
& =\frac{m p k_{t+1}^{2}-m p k_{t+1} R_{t}^{N}}{\rho \hat{\sigma}_{\hat{R}, t}^{2} R_{t}^{N}} \int_{\frac{1}{1-\delta}\left(R_{t}^{N}-m p k_{t+1}\right)}^{1} f(x) d x+ \\
& +\frac{m p k_{t+1}(1-\delta)}{\rho \hat{\sigma}_{\hat{R}, t}^{2} R_{t}^{N}} \int_{\frac{1}{1-\delta}\left(R_{t}^{N}-m p k_{t+1}\right)}^{1} x f(x) d x \\
& \frac{1-\delta}{\rho \hat{\sigma}_{\hat{R}, t}^{2}} W_{t} \int_{\frac{1}{1-\delta}\left(R_{t}^{N}-m p k_{t+1}\right)}^{1} x f(x) d x+ \\
& +\left(\frac{m p k_{t+1}-R_{t}^{N}}{\rho \hat{\sigma}_{\hat{R}, t}^{2}}\right) W_{t} \int_{\frac{1}{1-\delta}\left(R_{t}^{N}-m p k_{t+1}\right)}^{1} f(x) d x=K_{t} \\
& W_{t}\left(1+\frac{\left(m p k_{t+1}-R_{t}^{N}\right)^{2}}{\rho \hat{\sigma}_{\hat{R}, t}^{2} R_{t}^{N}}\right) \int_{\frac{1}{1-\delta}\left(R_{t}^{N}-m p k_{t+1}\right)}^{1} f(x) d x+ \\
& +\frac{W_{t}\left(m p k_{t+1}-R_{t}^{N}\right)(1-\delta)}{\rho \hat{\sigma}_{\hat{R}, t}^{2} R_{t}^{N}} \int_{\frac{1}{1-\delta}\left(R_{t}^{N}-m p k_{t+1}\right)}^{1} x f(x) d x=N_{t}
\end{aligned}
$$

In the above equations sums are approximated with integrals and limits of integration are the maximum and minimum of belief distribution. In (52) the first term represents lending on the interbank market where only banks with beliefs lower than $\frac{1}{1-\delta}\left(R_{t+1}^{N}-m p k_{t+1}\right)$ lend. The lower limit of the integration is the minimum possible belief realization about $\zeta_{t+1}$ which is zero. The right-hand side represents borrowing, when only banks with beliefs higher than $\frac{1}{1-\delta}\left(R_{t+1}^{N}-m p k_{t+1}\right)$ borrow, and the upper limit of the beliefs about $\zeta_{t+1}$ is 1 . The same logic applies to equations 
(53) and (54).

As was mentioned in the text with expert opinions following continuous uniform distribution, $f(x)=\frac{1}{b-a}$ and $F(x)=\frac{x-a}{b-a}$, with $a=0$ and $b=1$. It is straightforward to represent the distribution functions as functions of mean and standard deviation of banks' belief distribution. That is:

$$
\begin{aligned}
a & =\bar{x}-\sqrt{3} \sigma_{x}, b=\sqrt{3} \sigma_{x}+\bar{x} \\
f(x) & =\frac{1}{2 \sqrt{3} \sigma_{x}}, F(x)=\frac{x-\bar{x}+\sqrt{3} \sigma_{x}}{2 \sqrt{3} \sigma_{x}}
\end{aligned}
$$

After taking the integrals and log-linearizing (52),(53), (54) transform into:

$$
\begin{gathered}
\theta_{1} \overline{m p k}_{m p k}+\theta_{2} \bar{R}^{N} \hat{R}_{t+1}^{N}+\theta_{10} \bar{\sigma}_{R, t}^{2} \widehat{\widehat{\sigma}}_{\hat{R}, t}^{2}+\theta_{13} \overline{\bar{\zeta}} \widehat{\bar{\zeta}}_{t}+\theta_{14} \bar{\sigma}_{\zeta} \hat{\sigma}_{\zeta}=0 \\
\theta_{3} \bar{R}^{N} \hat{R}_{t+1}^{N}+\theta_{4} \overline{m p k} \widehat{\widehat{m p k}_{t+1}}+\theta_{5} \bar{W} \hat{W}_{t}+\theta_{11} \bar{\sigma}_{R}^{2} \widehat{\hat{\sigma}}_{\hat{R}}^{2}+\theta_{15} \overline{\bar{\zeta} \widehat{\zeta}_{t}}+\theta_{16} \bar{\sigma}_{\zeta} \hat{\sigma}_{\zeta, t}=\hat{k}_{t+1} \\
\theta_{6} \widehat{\overline{m p k}}_{\widehat{m p k}_{t+1}}+\theta_{7} \bar{R}^{N} \hat{R}_{t+1}^{N}+\theta_{8} \bar{W} \hat{W}_{t}+\theta_{12} \bar{\sigma}_{R}^{2} \widehat{\hat{\sigma}}_{\hat{R}}^{2}+\theta_{18} \overline{\bar{\zeta}} \widehat{\zeta}_{t}+\theta_{19} \bar{\sigma}_{\zeta} \hat{\sigma}_{\zeta}=\hat{n}_{t+1}
\end{gathered}
$$

where $\theta$ s are the parameters, $\widehat{\widehat{\sigma}}_{\hat{R}, t}^{2}, \widehat{\bar{\zeta}}_{t}, \hat{\sigma}_{\zeta, t}$ are log-deviations of the estimated variance of banks' prediction of $\zeta_{t+1}$, mean belief about $\zeta_{t+1}$, standard deviation of banks' beliefs (dispersion of beliefs among banks). The steady state values are denoted with $\bar{x}, \log$-linearized values are denoted with $\widehat{x}$. So, the equilibrium becomes the function of average investors' belief, dispersion of beliefs among them, and their assessment of return variance.

\section{B Natural Output}

We model the natural output as output of the economy were banks do not have an expert opinion shock, that is, they form homogeneous beliefs about risky asset return based on their econometric forecast:

$$
E_{t} \hat{\zeta}_{t+1}^{h}=E_{t}\left(\tilde{\zeta}_{t+1} \mid \zeta^{t}\right)=\hat{\rho}_{\zeta, t} \zeta_{t}
$$


Also, there are no price rigidities on the retail market: $\gamma=0$ and $P_{t}^{*}=\mu * P_{m, t}$.

Note that without heterogeneity of beliefs there is no interbank market. Then, without the possibility to borrow and lend on the interbank market, individual bank's problem becomes the following:

$$
\begin{gathered}
\max _{\omega, \gamma} \omega_{t}^{h} E_{t}^{h} \hat{R}_{k, t+1}^{h}+\left(1-\omega_{t}^{h}\right) R_{t}^{N}-\frac{\rho \hat{\sigma}_{\hat{R}, t}^{2}\left(\omega_{t}^{h}\right)^{2}}{2} \\
\omega_{t}^{h} \geq 0, \omega_{t}^{h} \leq 1
\end{gathered}
$$

with a solution:

$$
\omega_{t}^{h}=\frac{E_{t}^{h} \hat{R}_{k, t+1}^{h}-R_{t}^{N}}{\rho \hat{\sigma}_{\hat{R}, t}^{2}}=\omega_{t}
$$

The market clearing condition for capital is then:

$$
\omega_{t}\left(\Pi_{t} H+D_{t}\right)=K_{t}
$$

for reserves:

$$
\left(1-\omega_{t}\right)\left(\Pi_{t} H+D_{t}\right)=N_{t}
$$

Aggregate banks' budget constraint has not changed:

$$
\Pi_{t} H+D_{t}=K_{t}+N_{t}
$$

Combining equations (58), (59), (60), (61) with optimallity conditions of the household, final good producers, capital good producers, and retailers gives the solution for natural output.

\section{Estimation of the Shocks}

We estimate the mentioned time series as an ARIMA model on a time horizon up to the 4th quarter of 2007 (the onset of the crisis). The beginning of the database depends on data availability. To select the most appropriate model, the data were tested for unit root using ADF and KPSS tests. Afterwards, starting from the most 
parsimonious ARIMA model, the one with independent residual was selected. Residuals were checked by Portmanteau statistics, and the number of lags was selected by AIC criterion.

We then produce a forecast up to 2010. The sources of the data are in table 6 . We compare log differences of the realized series and the predicted ones. We use these differences as a proxy for deviations from the steady state. We understand that some variables might be in a boom stage up to 2007, so these deviations may be overestimated. The deviations of observed variables from a prediction based on pre-crisis data are taken for the 4th quarter of 2008, when (after Lehman Brothers collapse) most of the variables exhibited the highest deviation.

\begin{tabular}{|l|l|l|}
\hline Variable & Source & $\begin{array}{l}\text { Number } \\
\text { of obser- } \\
\text { vations } \\
\text { used in } \\
\text { estimation }\end{array}$ \\
\hline Real GDP & $\begin{array}{l}\text { IMF series 16399BVRZF, } \\
\text { GDP vol }\end{array}$ & 32 \\
\hline Credit & $\begin{array}{l}\text { IMF series 16360PCSZF, } \\
\text { Loans, corps, stocks, up to } \\
1 \text { year }\end{array}$ \\
\hline Investment & $\begin{array}{l}\text { IMF series 16393E.CZW, } \\
\text { Gross fixed cap. formation }\end{array}$ & 36 \\
\hline Market volatility & VIX, CBOE & 13 \\
\hline Business climate expectations & $\begin{array}{l}\text { Ifo world economic climate } \\
\text { for the Euro area, series "R } \\
3 \text { : Expectations next 6 } \\
\text { months" }\end{array}$ \\
\hline $\begin{array}{l}\text { Standard deviation of experts' } \\
\text { opinions }\end{array}$ & $\begin{array}{l}\text { ECB, SPF, series "Real } \\
\text { GDP growth" }\end{array}$ & 32 \\
\hline
\end{tabular}

Table 6: Data Description

We calibrate the liquidity provision shock as an expansion of the ECB's balance sheet in 2008 relative to 2007 . We use the values from Donati (2010). 


\section{Simulation with Alternative Parameter Values}

In the graphs below, panel a depict the response to a crisis shock and panel b to a crisis shock with liquidity provision policy. 


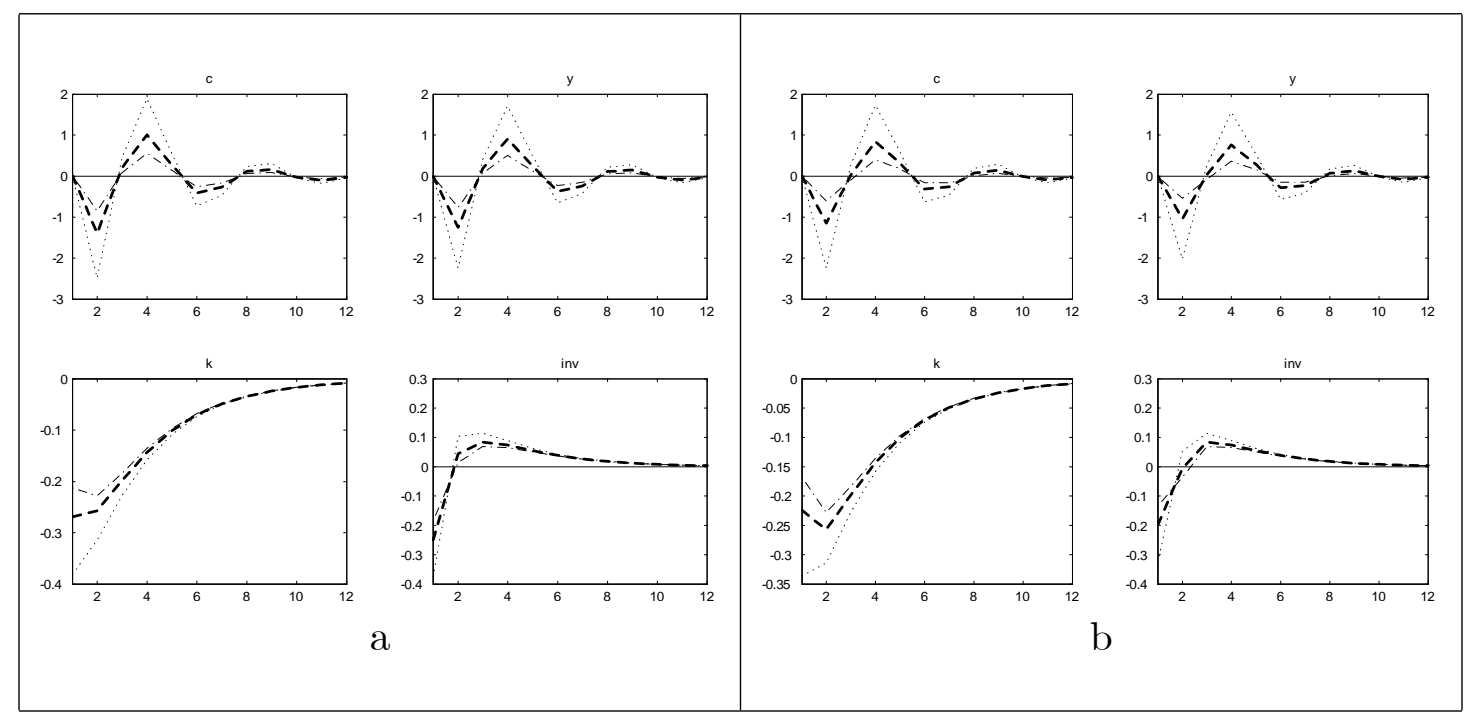

Figure 9: Impulse Responses to Crisis Shock with Alternative Share of Expert Adjustment

Notes: bold dashed line (-)- impulse responses under basic specification, dotted line (...) -with higher share of experts' adjustment, combined line (-.-) - with lower share of experts'adjustment. The following notation applies: y-output, c -consumption, $\mathrm{k}$ - capital, $\mathrm{r}$-deposit interest rate, $\mathrm{rn}$ safe asset interest rate, $\mathrm{n}$ - amount of reserves, l-labor supply, lend - interbank loans, inv investment, infl - inflation, i - nominal interest rate, $\mathrm{d}$ - deposits, wage - wage

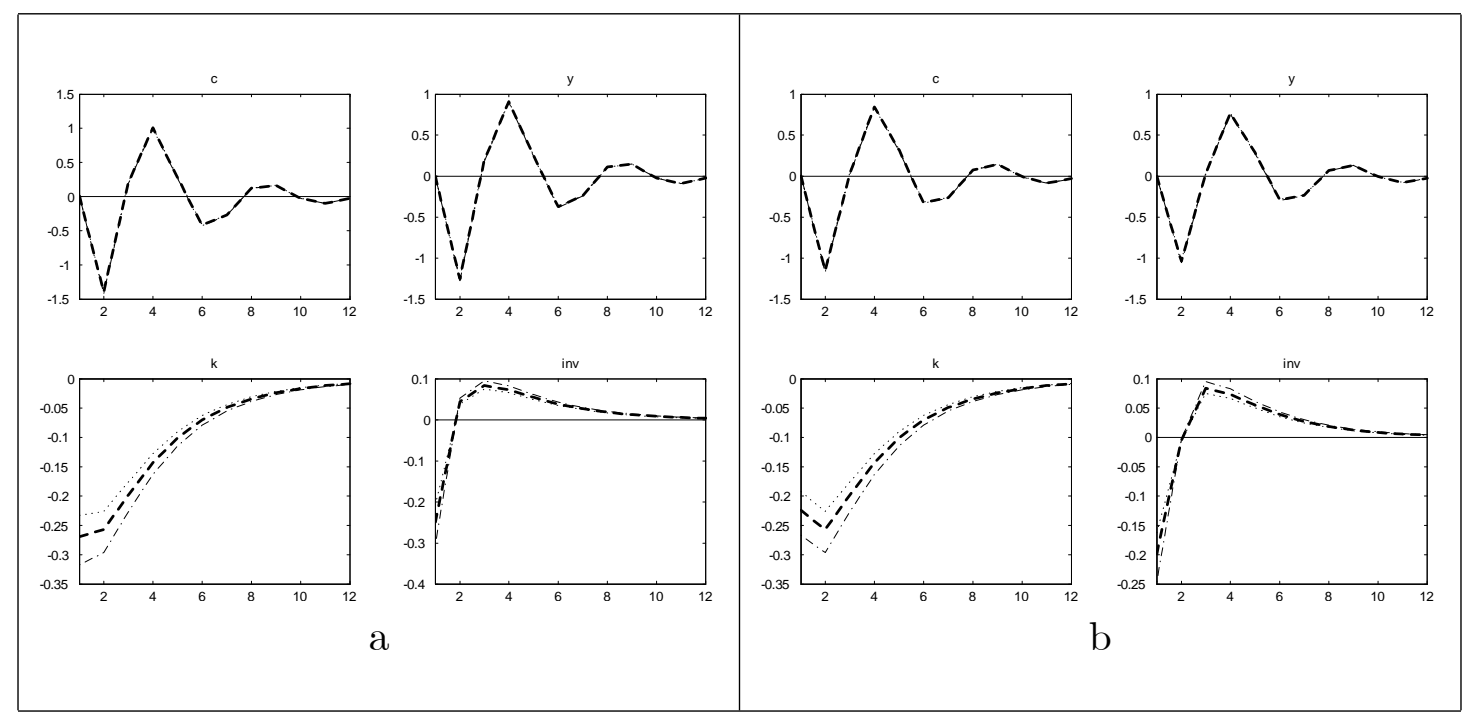

Figure 10: Impulse Responses to Crisis Shosk with Alternative Risk Aversion

Notes: bold dashed line $(-)$ - impulse responses under basic specification, dotted line (...) -with risk aversion, combined line (-.- ) - with higher risk aversion. The following notation applies: y-output, c -consumption, k- capital, $\mathrm{r}$-deposit interest rate, $\mathrm{rn}$ - safe asset interest rate, $\mathrm{n}$ amount of reserves, l-labor supply, lend - interbank loans, inv - investment, infl - inflation, i nominal interest rate, $\mathrm{d}$ - deposits, wage - wage 


\section{Working Paper Series}

ISSN 1211-3298

Registration No. (Ministry of Culture): E 19443

Individual researchers, as well as the on-line and printed versions of the CERGE-EI Working Papers (including their dissemination) were supported from institutional support RVO 67985998 from Economics Institute of the ASCR, v. v. i.

Specific research support and/or other grants the researchers/publications benefited from are acknowledged at the beginning of the Paper.

(c) Volha Audzei, 2012

All rights reserved. No part of this publication may be reproduced, stored in a retrieval system or transmitted in any form or by any means, electronic, mechanical or photocopying, recording, or otherwise without the prior permission of the publisher.

Published by

Charles University in Prague, Center for Economic Research and Graduate Education (CERGE) and

Economics Institute ASCR, v. v. i. (EI)

CERGE-El, Politických vězňu 7, 11121 Prague 1, tel.: +420 224005 153, Czech Republic.

Printed by CERGE-EI, Prague

Subscription: CERGE-EI homepage: http://www.cerge-ei.cz

Phone: + 420224005153

Email: office@cerge-ei.cz

Web: http://www.cerge-ei.cz

Editor: Michal Kejak

The paper is available online at http://www.cerge-ei.cz/publications/working_papers/.

ISBN 978-80-7343-281-2 (Univerzita Karlova. Centrum pro ekonomický výzkum a doktorské studium)

ISBN 978-80-7344-273-6 (Národohospodářský ústav AV ČR, v. v. i.) 
CERGE-EI

P.O.BOX 882

Politických vězňů 7

11121 Praha 1

Czech Republic http://www.cerge-ei.cz 